OPEN ACCESS

Edited by:

Mark S. Cragg,

University of Southampton,

United Kingdom

Reviewed by:

Aida Karachi,

University of Florida, United States

Andrew Steven Flies,

University of Tasmania, Australia

*Correspondence:

Kang $\mathrm{Li}$

kang.li@beigene.com

Tong Zhang

tong.zhang@beigene.com

Specialty section:

This article was submitted to

Molecular Innate Immunity,

a section of the journal

Frontiers in Immunology

Received: 30 November 2018 Accepted: 05 February 2019

Published: 26 February 2019

Citation:

Chen X, Song X, Li K and Zhang T

(2019) FC $\gamma R$-Binding Is an Important

Functional Attribute for Immune

Checkpoint Antibodies in Cancer

Immunotherapy.

Front. Immunol. 10:292.

doi: 10.3389/fimmu.2019.00292

\section{Fc $\gamma$ R-Binding Is an Important Functional Attribute for Immune Checkpoint Antibodies in Cancer Immunotherapy}

\author{
Xin Chen, Xiaomin Song, Kang Li* and Tong Zhang* \\ BeiGene (Beijing) Co., Ltd., Beijing, China
}

$T$ cells play critical roles in anti-tumor immunity. Up-regulation of immune checkpoint molecules (PD-1, PD-L1, CTLA-4, TIM-3, Lag-3, TIGIT, CD73, VISTA, B7-H3) in the tumor microenvironment is an important mechanism that restrains effector $\mathrm{T}$ cells from the anti-tumor activity. To date, immune checkpoint antibodies have demonstrated significant clinical benefits for cancer patients treated with mono- or combination immunotherapies. However, many tumors do not respond to the treatment well, and merely blocking the immune suppression pathways by checkpoint-regulatory antibodies may not render optimal tumor growth inhibition. Binding of the antibody Fc-hinge region to Fc gamma receptors (FcyRs) has been shown to exert a profound impact on antibody function and in vivo efficacy. Investigation of immune checkpoint antibodies regarding their effector functions and impact on therapeutic efficacy has gained more attention in recent years. In this review, we discuss Fc variants of antibodies against immune checkpoint targets and the potential mechanisms of how FcyR-binding could influence the anti-tumor activity of these antibodies.

Keywords: Fc $\gamma \mathrm{R}$, checkpoint blockade, antibody therapy, cancer immunotherapy, IgG isotype

\section{INTRODUCTION}

Immune checkpoints refer to multiple inhibitory pathways that control the immune system to maintain self-tolerance and modulate the intensity of physiological immune responses in order to minimize pathological damage (1-3). Antagonizing antibodies against immune checkpoint inhibitory molecules has achieved great success in cancer treatment $(1,2)$. However, many tumors do not respond to the treatment, and antibody optimization (especially in the isotype selection) is essential for improving outcomes $(4,5)$. target-binding specificity, imparted by the antibody's variable region, is well-known to be critical for the primary functional activities of the antibody. However, mounting evidence has shown that the antibody's constant region also plays a crucial role, much of which is mediated through interaction of the crystallizable fragment (Fc) with $\mathrm{Fc} \gamma$ receptors (Fc $\gamma \mathrm{Rs})(6)$. Fc endows IgG antibodies with effector functions, which include antibody dependent-cellular cytotoxicity (ADCC), complement-dependent cytotoxicity (CDC), antibody-dependent cellular phagocytosis (ADCP), Induction of cytokines/chemokines and endocytosis of opsonized targets (7).

To date, therapeutic IgG antibodies (either approved or in clinical development) belong to the IgG1, IgG2 or IgG4 subclasses. Each IgG isotype has a distinct binding affinity to the various Fc $\gamma$ Rs, 
which are expressed differently on immune cells. A combination of these features leads to diverse and highly regulated antibody responses.

Antagonizing antibodies against major T-cell inhibitory pathways, such as PD-1/PD-L1 and CTLA-4, have become important parts of cancer therapeutics (1). Consequently, the next wave of therapeutic antibodies targeting alternative immunosuppression pathways (e.g., LAG-3, TIM-3, B7-H3, VISTA, CD73) are rapidly emerging (8). The majority of the immune checkpoint antibodies have low or significantly reduced binding to $\mathrm{Fc} \gamma \mathrm{Rs}$ to avoid potential ADCC and CDC, especially when the target molecule is expressed on effector $\mathrm{T}$ cells (9). However, for targets such as CTLA-4, TIGIT, and VISTA, competent Fc is required for optimal anti-tumor immune responses in various mouse models (10-12). The mechanisms of action (MOA) may involve the killing of regulatory $\mathrm{T}$ cells (Tregs), promoting immune synapse formation and production of pro-inflammatory cytokines due to cross-linking of Fc $\gamma$ Rs with the competent Fc.

In this article, we summarize the major properties of different IgG isotypes and Fc $\gamma$ Rs, describe the MOA of different immune checkpoint targets in inhibiting anti-tumor immunity and review the recent studies on the important roles of either binding or not binding to $\mathrm{Fc} \gamma \mathrm{Rs}$ in immune checkpoint antibody therapy. It should be noted that many of the findings come from mouse models; the clinical significance of these findings has yet to be determined.

\section{IgG ISOTYPES AND Fc $\gamma$ RS}

In humans, there are four isotypes of $\operatorname{IgG}$ (IgG1-4), differing from the other in their binding profiles to various Fc $\gamma$ Rs and to complement subunits, such as C1q. IgG1 has the highest affinity to all $\mathrm{Fc} \gamma \mathrm{Rs}$ and $\mathrm{C1q}$, leading to significant effector functions, such as ADCC, ADCP, and CDC $(5,13)$. Although human IgG3 can also mediate competent effector functions, it has a very long hinge region and complex disulfide bonds, resulting in significantly greater polymorphism, which may increase the risk of immunogenicity. Therefore, the IgG3 isotype is rarely chosen in antibody therapeutics (14) and is not further discussed in this review. In comparison, IgG2 and IgG4 induce significantly weaker or no ADCC and CDC (13). The binding features of different $\mathrm{IgG}$ isotypes to various $\mathrm{Fc} \gamma \mathrm{Rs}$ are summarized in Table 1 and discussed below.

The overall structures of IgG1, IgG2, and IgG4 are very similar with more than $90 \%$ sequence homology. The major differences reside in the hinge region and $\mathrm{CH} 2$ domain, which form primary binding sites to Fc $\gamma$ Rs (19-21). The hinge region also functions as a flexible linker between the Fab and Fc portion.

In addition to differential binding affinity to Fc $\gamma$ Rs, IgG4, and IgG2 demonstrate other unique features. IgG4 has a unique $S_{228}$ in the hinge region, which allows for interchangeable disulfide bond configurations and formation of "half-antibodies" (22). In vivo, IgG4 with different specificity may shuffle, resulting in monovalent-bispecific antibodies (a process called "Fab-arm exchange") (23). S 228 P mutation of IgG4 can efficiently eliminate
TABLE 1 | Binding activities of human FC $\gamma R$ to $\lg G$ isotypes and resulting effector functions.

\begin{tabular}{|c|c|c|c|c|c|c|c|}
\hline \multirow[t]{2}{*}{$F c \gamma R$} & \multirow[t]{2}{*}{ Variants } & \multicolumn{2}{|c|}{ IgG1 } & \multicolumn{2}{|r|}{ IgG2 } & \multicolumn{2}{|r|}{ IgG4 } \\
\hline & & Affinity $^{a}$ & $\begin{array}{l}\text { Effector } \\
\text { functions }\end{array}$ & Affinity & $\begin{array}{l}\text { Effector } \\
\text { functions }\end{array}$ & Affinity & $\begin{array}{l}\text { Effector } \\
\text { functions }\end{array}$ \\
\hline | & NA & High & $\mathrm{ADCP}$ & None & None & High & $\begin{array}{l}\text { ADCP, } \\
\text { Cytokine } \\
\text { release }\end{array}$ \\
\hline \multirow{2}{*}{ Ila } & $\mathrm{H}_{131}$ & Medium & \multirow{2}{*}{ ADCP } & Medium & \multirow{2}{*}{$\begin{array}{l}\text { Myeloid } \\
\text { cell-induced } \\
\text { ADCC }\end{array}$} & Low & \multirow{2}{*}{$\begin{array}{l}\text { Receptor } \\
\text { clustering }{ }^{\mathrm{C}}\end{array}$} \\
\hline & $R_{131}$ & Low & & Low & & Low & \\
\hline \multirow{2}{*}{$\| \mathrm{lb}$} & $I_{232} d$ & \multirow{2}{*}{ Low } & \multirow{2}{*}{$\begin{array}{l}\text { Clearance of } \\
\text { IC, Immuno- } \\
\text { suppression }\end{array}$} & \multirow{2}{*}{ None } & \multirow{2}{*}{ None } & \multirow{2}{*}{ Low } & \multirow{2}{*}{$\begin{array}{l}\text { Clearance of } \\
\text { IC, Immuno- } \\
\text { suppression }\end{array}$} \\
\hline & $T_{232} d$ & & & & & & \\
\hline \multirow{2}{*}{ Illa } & $V_{158}$ & Medium & \multirow{2}{*}{$A D C C$} & Low & \multirow{2}{*}{ None } & Low & \multirow{2}{*}{ None } \\
\hline & $F_{158}$ & Low & & None & & None & \\
\hline
\end{tabular}

${ }^{a}$ Affinity values are based on IC binding to $F_{C} \gamma R$, adapted from Bruhns et al. (13).

${ }^{b}$ Based on Arce Vargas et al. (15).

${ }^{c}$ Based on Oberst et al. (16).

${ }^{d}$ The $T_{232}$ variant is less potent in inhibitory activity than the $I_{232}$ variant (17). However, the $I_{232} T$ mutation leads to significantly better phagocytosis (18).

fab-arm change. Therefore, the majority of recently approved therapeutic IgG4 antibodies adopt an $\mathrm{S}_{228} \mathrm{P}$ mutation (24). In IgG2, several disulfide bond isomers (IgG2A, IgG2B, and IgG2A/B) can be formed $(25,26)$. Many factors such as cell culture conditions or thermal stress contribute to the formation and equilibrium of different isomers (27). In vivo, IgG2A isomer can convert to the form of IgG2B (28). Among the three isomers, IgG2B has the most compact structure (26). In addition, as compared to the form of IgG2A, the IgG2B conformation imparts super-agonistic properties to immunostimulatory antibodies, such as anti-CD40 antibodies (29). The feature of IgG2 isomer transformation is Fc $\gamma \mathrm{R}$-independent and its activity has been demonstrated for IgG2 CD40 mAb in the clinical trial CP870-893 (29).

In mice, IgG2A functionally resembles human IgG1, whereas mouse IgG1 is considered the closest functional equivalent of human IgG4. The $\mathrm{D}_{265} \mathrm{~A}$ mutation can further reduce the affinity of mouse IgG1 for the Fc receptor, leading to a "silent Fc" and antibodies harboring this mutation have been widely used in mouse models to evaluate the effects of $\mathrm{Fc} \gamma \mathrm{R}$-binding on in vivo therapeutic efficacy (30-32).

Based on the differences in structure, function, and affinity for IgG binding, $\mathrm{Fc} \gamma \mathrm{Rs}$ are classified into three major groups: Fc $\gamma$ RI, Fc $\gamma$ RII (Fc $\gamma$ RIIa and Fc $\gamma$ RIIb) and Fc $\gamma$ RIII (Fc $\gamma$ RIIIa and Fc $\gamma$ RIIIb) (13). Among them, Fc $\gamma$ RI, Fc $\gamma$ RIIa, and Fc $\gamma$ RIIIa are activating receptors containing the signal transduction motif, immunoreceptor tyrosine-based activation motif (ITAM), in the $\gamma$ subunit of Fc $\gamma$ RI and Fc $\gamma$ RIIIa, or in the cytoplasmic tail of Fc $\gamma$ RIIa (14). In contrast, Fc $\gamma$ RIIb is an inhibitory receptor. Cross-linking of FcyRIIb leads to the phosphorylation of the immunoreceptor tyrosine-based inhibitory motif (ITIM) and inhibitory signaling transduction (33).

\section{Fc $\gamma \mathbf{R I}$}

Fc $\gamma$ RI is a high-affinity Fc receptor for both the monomeric IgG and immune complex (IC) (13). The affinities of Fc $\gamma$ RI 
to IgG1 or IgG4 are similar ( $K_{D}$ of $\left.1-10 \mathrm{nM}\right)$. In contrast, Fc $\gamma$ RI has no binding to IgG2. Fc $\gamma$ RI is mainly expressed on monocytes/macrophages, dendritic cells (DCs), and activated neutrophils. One of the major functions of Fc $\gamma \mathrm{RI}$ is to activate myeloid cells to phagocytose IgG1 and IgG-bound target cells via ADCP (34). Due to high-affinity binding of Fc $\gamma$ RI to monomeric IgG and high serum concentrations of $\operatorname{IgG}(\sim 15 \mathrm{mg} / \mathrm{mL})$, it is believed that most Fc $\gamma$ RI is occupied by endogenous IgG (35). However, a recent study has shown that stimulation of myeloid cells with cytokines, such as tumor necrosis factor- $\alpha$ (TNF- $\alpha)$ and interferon- $\gamma$ (IFN- $\gamma)$, could induce the clustering of Fc $\gamma$ RI and increase the binding of Fc $\gamma$ RI to ICs (36). Multiple studies have also shown that Fc $\gamma$ RI plays an important role in modulating immune responses in autoimmune diseases, inflammation, and antibody therapy (37-39).

\section{Fc $\gamma$ RIIA AND Fc $\gamma$ RIIIA}

Both Fc $\gamma$ RIIa and Fc $\gamma$ RIIIa are low-affinity Fc $\gamma$ Rs, which bind weakly to monomeric IgG, but strongly to IC. Fc $\gamma$ RIIa and Fc $\gamma$ RIIIa receptors are primarily expressed on monocytes/macrophages, dendritic cells, natural killer cells and platelets. Fc $\gamma$ R polymorphisms exist in Fc $\gamma$ RIIa and Fc $\gamma$ RIIIa receptors, resulting in two isoforms of each receptor: $\mathrm{H}_{131}$ and $\mathrm{R}_{131}$ of $\mathrm{Fc} \gamma \mathrm{RIIa}(40), \mathrm{V}_{158}$ and $\mathrm{F}_{158}$ of Fc $\gamma$ RIIIa (41), respectively. $\mathrm{Fc} \gamma \mathrm{RIIa}-\mathrm{H}_{131}$ variant is considered a high responder as compared to $R_{131}$ variant (low responder) due to a higher affinity for IgG1 and increased effector functions (such as phagocytosis) $(13,22)$. Similar to Fc $\gamma$ RI, Fc $\gamma$ RIIa is one of the major phagocytic Fc $\gamma$ Rs that mediates ADCP. In human, Fc $\gamma$ RIIIa is the primary receptor for NK- and macrophage-mediated ADCC. Fc $\gamma$ RIIIa-V 158 variant (high responder) has a higher affinity for IgG1 and can also interact with IgG4 (13). Functionally, IgG-induced NK cell activity is increased in Fc $\gamma$ RIIIA-V/V 158 homozygotes compared with Fc $\gamma$ RIIIA-F/F 158 individuals (42).

\section{Fc $\gamma$ RIIB}

Fc $\gamma$ RIIb is expressed on many types of immune cells including B cells, DCs, monocytes/macrophages, mast cells and basophils (33). In addition, Fc $\gamma$ RIIb was found to be expressed on liver sinusoidal endothelial cells (LSEC) and plays an important role in IC clearance (43). On B cells, Fc $\gamma$ RIIb functions as a primary inhibitory $\mathrm{Fc} \gamma \mathrm{R}$ to suppress $\mathrm{B}$ cell activation and antigen internalization after binding to the immune complex (33). Fc $\gamma$ RIIb also inhibits the type I interferon production by DCs. The binding affinities of monomeric IgG to Fc $\gamma$ RIIb are extremely low $\left(K_{A} \approx 2 \times 10^{5} \mathrm{M}^{-1}\right)$, whereas the affinities of IC to Fc $\gamma$ RIIb are significantly higher (13). Despite the critical roles of $\mathrm{Fc} \gamma \mathrm{RIIb}$ in the negative regulation of immune responses, several studies have shown that Fc $\gamma$ RIIb is required for the induction of efficient anti-tumor activity by agonistic anti-TNF receptor superfamily-antibody therapeutics such as anti-CD40 antibodies $(44,45)$. The overall binding features of human Fc $\gamma \mathrm{R}$ to IgG isotypes are summarized in Table $\mathbf{1 .}$

\section{MOUSE Fc $\gamma$ RIV}

In addition to the Fc $\gamma$ Rs described above, in mice, there is a unique $\mathrm{Fc} \gamma \mathrm{R}$ (i.e., Fc $\gamma \mathrm{RIV}$ ), whose expression is restricted to myeloid lineage cells (46). FcyRIV bind to mouse IgG2a and IgG2b with intermediate affinity and plays critical roles in IgG2aand IgG2b-mediated in vivo efficacy $(46,47)$. Mouse Fc $\gamma$ RIV is functionally similar to human Fc $\gamma$ RIIIa, but not expressed on natural killer cells (47). In a mouse model, anti-CTLA-4 antibody-mediated depletion of Tregs is largely dependent on Fc $\gamma$ RIV (10).

\section{Fc ENGINEERING TO REDUCE OR ELIMINATE Fc $\gamma$ R BINDING}

Several modifications to IgG can directly affect their binding to Fc $\gamma$ Rs. The $\mathrm{N}_{297} \mathrm{~A}$ mutation was the first mutation to be described with significantly reduced Fc $\gamma$ R-binding (48). It was later demonstrated that mutations of residues 234 and 235 in the lower hinge region (EU numbering system) to alanine could also lead to significantly reduced Fc $\gamma$ R-binding; the $\mathrm{L}_{234} \mathrm{~A} / \mathrm{L}_{235} \mathrm{~A}$ double mutation on the human IgG1 backbone is also known as the "LALA" mutation (49). In addition, hybrid antibody isotype $\operatorname{IgG} 2 \mathrm{~m} 4$, which is based on the IgG2 with four key amino acid residue changes derived from IgG4 $\left(\mathrm{H}_{268} \mathrm{Q}, \mathrm{V}_{309} \mathrm{~L}, \mathrm{~A}_{330} \mathrm{~S}\right.$, and $\mathrm{P}_{331} \mathrm{~S}$ ), has been shown to have significantly reduced $\mathrm{Fc} \gamma \mathrm{R}$ binding (50).

\section{IMMUNE CHECKPOINT MOLECULES AND THEIR THERAPEUTIC ANTIBODIES}

\section{CTLA-4}

CTLA-4 (cytotoxic T-lymphocyte-4, or CD152) is a member of the Ig superfamily, which plays a critical role in inhibiting $\mathrm{T}$ cell immunity (51). The ligands are the B7 family members, CD80 (B7-1) and CD86 (B7-2). As a CTLA-4-related protein, CD28 is constitutively expressed on naïve $\mathrm{T}$ cells and enhances $\mathrm{T}$-cell activation when engaged by $\mathrm{B} 7-1 / 2$ on antigen-presenting cells (APC) $(52,53)$. In contrast, CTLA-4 surface expression increases in a day or two after T cell activation $(51,52)$. CTLA4 is also highly expressed on Tregs and plays an important role in the homeostasis and suppressive functions of Tregs (54). There is no known canonical immunoreceptor tyrosinebased inhibitory (ITIM) motif in the cytoplasmic tail of CTLA-4 (55). The exact signaling pathway of CTLA-4 upon engagement with its ligands still remains largely unknown. Accumulating evidence suggested that CTLA-4 primarily exerted its inhibitory functions by competing off CD28 binding to CD80 and/or CD86, due to the higher affinity of CTLA4 to CD80 or CD86 (55). In addition, CTLA-4 has been shown to down-regulate CD80 and CD86 on APC, thus inhibiting CD28-mediated co-stimulation (54).

In mouse tumor models (melanoma and colorectal cancer), several groups have clearly shown that surrogate anti-CTLA4 antibody-mediated anti-tumor efficacy is dependent on Fc 

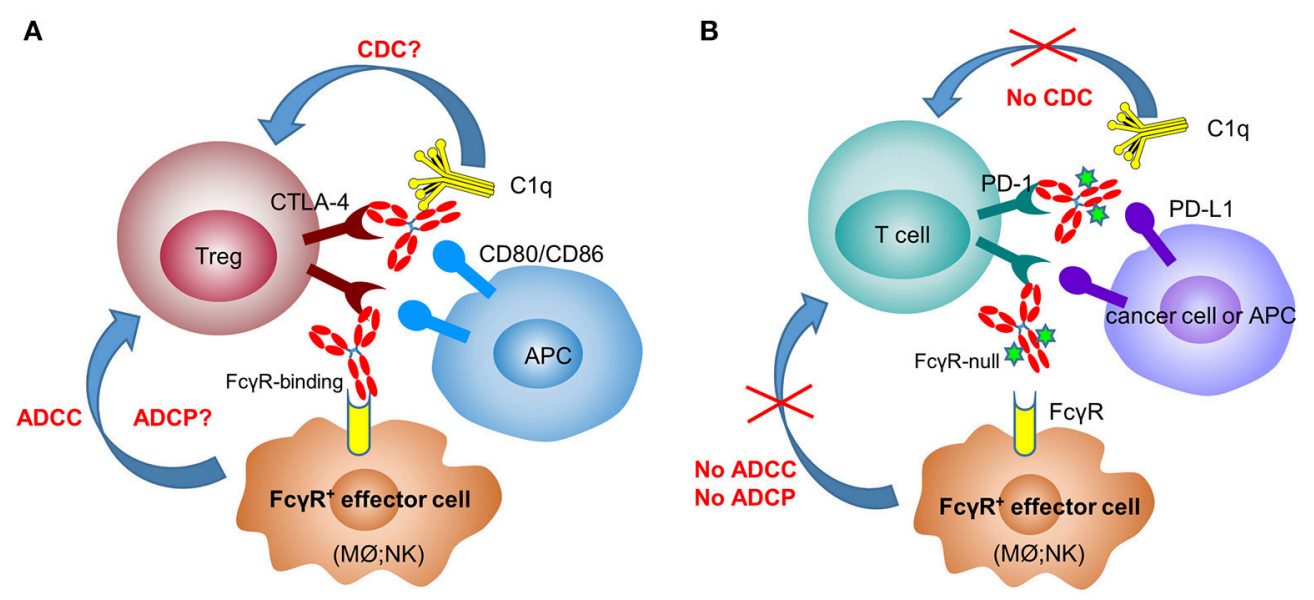

FIGURE 1 | Anti-CTLA-4 and anti-PD-1 therapeutic antibodies have differential FcyR-binding requirement for optimal activity. In the mechanisms of action of anti-CTLA-4 antibodies (A), depletion of Tregs after engaging Fc $\gamma \mathrm{R}^{+}$effector cells [macrophages (M $\left.\phi\right)$ and NK cells] plays a critical role in their efficacy. In contrast, anti-PD-1 antibodies need to have the Fc-mediated effector functions (ADCC, ADCP, and CDC) removed to avoid the killing of PD-1+ ${ }^{+}$cells by FC $\gamma \mathrm{R}^{+}$effector cells (B).

effector functions and correlate with depletion of tumorinfiltrating Tregs (10, 30, 56) (Figure 1A). In 2011, the FDA approved the first anti-CTLA-4 antibody, ipilimumab (IgG1 wild-type), for the treatment of melanoma. Furthermore, the combination of PD-1 blockade with ipilimumab demonstrated increased, durable anti-tumor activity in renal cell carcinoma and non-small cell lung cancer (NSCLC) $(57,58)$. Interestingly, anti-CTLA-4 clones, which lose the ability to block the B7CTLA-4 interaction, remain fully active in inducing tumor rejection, suggesting that other mechanisms are involved in anti-CTLA-4 antibody-mediated anti-tumor efficacy besides the blocking of B7-CTLA-4 (59). In an ex-vivo assay, melanoma patient-derived non-classical monocytes could kill Tregs via ADCC (60). In addition, patients who responded to ipilimumab tended to have a higher percentage of $\mathrm{CD} 14^{+} \mathrm{CD} 16^{+}$monocytes in the periphery. Using human Fc $\gamma \mathrm{R}$-transgenic mice, Arce Vargas et al. clearly demonstrated that antibodies with isotypes equivalent to ipilimumab increased the $\mathrm{CD} 8^{+}$to Treg ratio by depleting intra-tumoral Tregs to promote tumor rejection (15). Furthermore, a response to ipilimumab in melanoma patients is associated with a high-affinity Fc $\gamma$ RIIIa (CD16-V 158 ) polymorphism. A second anti-CTLA- $4 \mathrm{mAb}$, tremelimumab, is a human IgG2 isotype with minimal Fc $\gamma$ RIIIa-mediated ADCC effects (61). However, anti-mouse CTLA-4 antibody with human IgG2 isotype could also deplete Tregs in human Fc $\gamma$ R-transgenic mice in a Fc $\gamma$ RIIa-dependent manner (15). Despite the convincing data from mouse models, there has not been direct evidence indicating that anti-CTLA4 immunotherapy could efficiently deplete Tregs in human cancers $(62,63)$.

\section{PD-1/PD-L1}

In recent years, immune therapy targeting the PD-1/PD-L1 pathway has become a backbone clinical strategy for cancer treatment. Programmed cell death 1 (PD-1) is an inhibitory immune modulatory receptor (64-66). It is inducibly expressed on activated T, NK, and B lymphocytes (67), macrophages, DCs (68), and monocytes (69) as an immune suppressor for both adaptive and innate immune responses. PD-1 is highly expressed on tumor-specific T cells. Engagement of PD-1 by its ligands, PD-L1 (70) or PD-L2 $(71,72)$ leads to the exhaustion of T cell function and immune tolerance in the tumor microenvironment. Blockade of $\mathrm{PD}-1$ pathway has been shown to restore the function of "exhausted" $\mathrm{T}$ cells, resulting in significant antitumor activity $(70,73)$. To date, five PD-1 antibodies have been approved and many others are under development for the treatment of a broad spectrum of cancers (Table 2). Most of these anti-PD-1 antibodies are of IgG4 isotype with the $\mathrm{S}_{228} \mathrm{P}$ mutation (IgG4 $\mathrm{S}_{228} \mathrm{P}$ ), which has similar effector-binding properties as the natural IgG4 with reduced ADCC and "null" CDC, but still retaining high affinity to Fc $\gamma \mathrm{RI}$ and binding to Fc $\gamma$ RIIb. In the MC38 mouse model, Dahan et al. reported that engagement of $\mathrm{Fc} \gamma \mathrm{Rs}$ reduced the anti-tumor activity of an anti-PD-1 antibody by eliminating $\mathrm{CD}^{+}$tumor-infiltrating lymphocytes (TILs) via ADCC in a Fc $\gamma$ RI-dependent manner (9). In addition, engagement of Fc $\gamma$ RIIb by an anti-PD-1 antibody could also decrease its anti-tumor activities. Arlauckas et al. demonstrated that anti-PD-1 antibodies can be captured from the T-cell surface by Fc $\gamma$ R-bearing macrophages. The blockade of Fc $\gamma$ Rs could thus prolong the binding of the anti-PD-1 antibody to $\mathrm{CD}^{+}$TILs and enhance the anti-tumor activity in vivo (74). A preclinical study by our group also suggested that Fc $\gamma$ RI binding had a negative impact on the anti-tumor activity of anti-PD-1 antibodies in a humanized xenograft model. The binding could induce $\mathrm{Fc} \gamma \mathrm{RI}^{+}$macrophages to phagocytose $\mathrm{PD}-1^{+} \mathrm{T}$ cells via ADCP and reverse the function of an antiPD-1 antibody from blocking to activating (37). Recently, several published research papers documented the phenomenon that the 
TABLE 2 | Select PD-1 and PD-L1 antibodies under development for cancer treatment.

\begin{tabular}{|c|c|c|c|c|}
\hline Target & Company & mAb & $\begin{array}{l}\text { Clinical } \\
\text { stages }\end{array}$ & $\begin{array}{l}\text { IgG isotype or } \\
\text { mutant with effector } \\
\text { function nullified }\end{array}$ \\
\hline PD-1 & $\begin{array}{l}\text { Bristol-Myers } \\
\text { Squibb }\end{array}$ & Nivolumab & Approved & $\operatorname{lgG} 4 \mathrm{~S}_{228} \mathrm{P}$ \\
\hline PD-1 & Merck & Pembrolizumab & Approved & $\operatorname{lgG} 4 \mathrm{~S}_{228} \mathrm{P}$ \\
\hline PD-1 & Regeneron/Sanofi & Cemiplimab & Approved & $\operatorname{lgG} 4 \mathrm{~S}_{228} \mathrm{P}$ \\
\hline PD-1 & Novartis & Spartalizumab & Phase 3 & $\operatorname{lgG} 4 \mathrm{~S}_{228} \mathrm{P}$ \\
\hline PD-1 & BeiGene & Tislelizumab & Phase 3 & IgG4mut, Fc $\gamma R$ null \\
\hline PD-1 & Junshi & JS001 & Approved & $\operatorname{lgG} 4 \mathrm{~S}_{228} \mathrm{P}$ \\
\hline PD-1 & Hengrui & Camrelizumab & Phase 3 & $\operatorname{lgG} 4 \mathrm{~S}_{228} \mathrm{P}$ \\
\hline PD-1 & Innovent & Sintilimab & Approved & $\operatorname{lgG} 4 \mathrm{~S}_{228} \mathrm{P}$ \\
\hline PD-L1 & Roche & Atezolizumab & Approved & IgG1mut, Fc $\gamma R$ null \\
\hline PD-L1 & AstraZeneca & Durvalumab & Approved & IgG1mut, Fc $\gamma R$ null \\
\hline PD-L1 & $\begin{array}{l}\text { Merck } \\
\text { KGaA/Pfizer }\end{array}$ & Avelumab & Approved & $\lg G 1$ \\
\hline
\end{tabular}

hyperprogression frequencies of certain cancer types treated with FDA-approved anti-PD-1 antibodies were substantially higher than the control chemotherapy group (75-77). Lo Russo et al. linked the interaction between the anti-PD-1 antibody and $\mathrm{Fc} \gamma \mathrm{R}^{+}$macrophages to the hyperprogression in NSCLC during PD-1 blockade therapy (78). Based on these observations, an anti-PD-1 antibody with pure blocking activity would be more desirable, since an anti-PD-1 antibody with Fc $\gamma$ R-binding activity can mediate cross-linking between PD- ${ }^{+}$T-cells and $F c \gamma \mathrm{R}^{+}$ macrophages, induce the depletion of $\mathrm{PD}-1^{+} \mathrm{T}$ effector cells, and thus compromise the T-cell activity of tumor growth inhibition $(9,37,74)$ (Figure 1B).

Programmed death ligand 1 (PD-L1) is constitutively expressed by immune cells of myeloid lineages (79) and the cells at immune-privileged sites $(80,81)$. It is also inducibly expressed on T, NK and B lymphocytes, epithelial and endothelial cells upon stimulation by pro-inflammatory factors, such as IFN$\gamma$ and TNF- $\alpha$ (82). PD-L1 is the main ligand of PD-1, and the PD-L1/PD-1 axis is the major controller of the peripheral immune tolerance (65). In tumors, PD-L1 is expressed on both tumor cells (83) and tumor-infiltrating immune cells and can suppress anti-tumor immunity independently (84). Unlike antiPD-1 antibodies, the three approved PD-L1 antibodies have differentiated Fc $\gamma$ R-binding properties (Table 2). Atezolizumab and durvalumab are designed to eliminate $\mathrm{Fc} \gamma \mathrm{R}$-binding and effector functions $(85,86)$, while avelumab retains intact Fc functions (87). Recent preclinical data suggested that the engagement of Fc $\gamma$ Rs could augment the anti-tumor activity of anti-PD-L1 antibodies via the ADCC effect against the PD$\mathrm{L}^{+}$immune suppressive myeloid cells (88) or tumor cells (89). However, it is also speculated that the effector function could be detrimental to the anti-tumor immunity due to the depletion of PD-L1 ${ }^{+}$APC cells and T effector cells. To understand the role of Fc $\gamma$ R-binding on anti-PD-L1 anti-tumor efficacy, future studies are needed to elucidate the expression of PD-L1 in the tumor microenvironment and the effect of anti-PD-L1 antibody treatment.

\section{TIM-3}

TIM-3 (T cell immunoglobulin and mucin-domain containing3, also known as HAVCR2) is a member of the T-cell immunoglobulin- and mucin-domain-containing family that plays an important role in promoting T-cell exhaustion in both chronic viral infections and tumor escape from immune surveillance $(90,91)$. It is primarily expressed on immune cells, such as T cells, NK cells, DCs, and monocytes/macrophages (92). When expressed on effector T cells, activation of TIM-3 has been shown to reduce cytokine production, T-cell proliferation, and cytotoxicity, all of which could be rescued by TIM-3 blocking antibodies $(93,94)$. TIM-3 is also expressed on FoxP3 ${ }^{+}$Treg cells, especially in human tumor tissues, and is correlated with poor clinical parameters $(95,96)$.

Four TIM-3 ligands have been identified, which include PtdSer, Gal-9, carcinoembryonic antigen-related cell adhesion molecule 1, and high mobility group box 1 (97). To date, the detailed mechanisms of TIM-3 signaling remain unclear. Upregulation of TIM-3 expression in TILs, macrophages, and tumor cells has been reported in many types of cancers (98-101). Increased expression of TIM-3 in those cancers is associated with a poor prognosis and/or patient survival.

Following PD-1 antibody blockade, TIM-3 expression has been shown to be upregulated on TILs from both patient samples and animal models, resulting in "adaptive resistance" to anti-PD1 treatment (102-104). Blockade of the TIM-3 receptor alone or in combination with PD-1/PD-L1 blockade has been shown both in vitro and in vivo to rescue functionally "exhausted" $\mathrm{T}$ cells $(3,93,105)$.

In pre-clinical mouse models of colorectal cancer (MC38 and CT26), the effects of "silent" Fc vs. "competent" Fc on TIM-3 antibody-mediated anti-tumor activity with or without anti-PD-1 antibody treatment were evaluated by several groups $(106,107)$. The results showed that the combination of "Fc-silent" TIM-3 Ab with PD-1 Ab led to significantly more synergistic tumor-inhibitory effects than the one with "competent" Fc, while TIM-3 blocking Ab monotherapy demonstrated marginal antitumor efficacy. The exact mechanisms of Fc effector functions (ADCC and/or ADCP) in the negative regulation of anti-TIM-3 antibody-mediated anti-tumor efficacy remain unknown.

To date, the first-in-human phase $1 / 2$ clinical trials have been initiated for four anti-TIM-3 antibodies: TSR-022 (NCT02817633), MBG543 (NCT02608268), BMS-986258 (NCT03446040), and LY3321367 (NCT03099109). TESARO recently released the clinical data of TSR-022, in monotherapy or in combination with an anti-PD-1 antibody (TSR-042) in patients who progressed following anti-PD-1 treatment (108). The results showed that the combination of TSR-022 and TSR042 (500 mg) was generally well-tolerated in both NSCLC and melanoma patients, and clinical activities have been observed in the combination therapy, especially at a high dose of TSR-022 $(300 \mathrm{mg})$ with an objective response rate (ORR) of $15 \%(3 / 20)$ and $40 \%$ stable disease $(8 / 20)(108)$. 


\section{LAG-3}

LAG-3 (Lymphocyte activation gene-3, or CD223) is a member of the immunoglobulin superfamily (IgSF) (109). The immuneregulatory roles of LAG-3 were demonstrated in LAG-3 knockout mice, in which increased susceptibility to autoimmune diseases was observed $(110,111)$. LAG-3 is primarily expressed on activated $\mathrm{T}$, natural killer (NK), and plasmacytoid dendritic cells (pDC), but not on resting $\mathrm{T}$ cells $(109,112)$. In addition, LAG-3 expression on Tregs is positively correlated with their immune-suppressive activity (113). Sequence homology analysis revealed that LAG-3 is structurally related to CD4, but with higher affinity (60 nM) to MHC class II (MHC-II) molecules, thus inhibiting CD4-MHC-II interaction and negatively regulating T-cell receptor (TCR) signaling $(109,114)$. In addition, LAG3 can exert negative regulation of $\mathrm{CD}^{+} \mathrm{T}$ cells via $\mathrm{CD} 4^{+} \mathrm{T}$ cell-dependent and/or independent manners $(115,116)$. Similar to PD-1, LAG-3 is expressed on tumor-infiltrating lymphocytes (TILs), but to a less extent. Besides MHC-II molecules, LAG3 has been shown to bind to galectin-3 (Gal-3) and LSECtin $(115,117)$. The exact biological function of these two ligands binding to LAG-3 remains unknown. Recently, fibrinogenlike protein 1 (FGL1) has been identified as a novel highaffinity ligand for LAG-3 (118). In vitro, FGL1 could induce T-cell inhibition in a LAG-3-dependent manner. In the MC38 colorectal cancer model, ablation of FGL1-LAG-3 interaction with either anti-FGL1 or anti-LAG-3 blocking antibodies inhibits tumor growth.

In mouse tumor models (Sa1N fibrosarcoma, MC38 colorectal cancer, and MBT-2 bladder cancer), dual blockade of LAG3 and PD-1 receptors with blocking antibodies has shown to significantly improve the anti-tumor activity than either antibody alone $(111,119)$. In a study by Jun et al., a pair of anti-mouse LAG-3 surrogate antibodies with IgG1 (D265A) [anti-mLAG3 IgG1(D265A)] or IgG2a (anti-mLAG-3 IgG2a) isotypes were generated based on a commercial clone (C9B7W). Comparative study of these two antibodies either alone or in combination with anti-mouse PD-1 antibody in the CT26 mouse colorectal cancer model showed that anti-mouse LAG-3 antibody with minimal Fc effector functions [IgG1 (D265A)] had anti-tumor efficacy, and the one with effector function (IgG2a) had no apparent tumor inhibitory effect (120). In addition, when combined with PD-1 blocking antibody, anti-mLAG-3 IgG1 (D265A) showed significantly synergistic anti-tumor effects, whereas antimLAG-3 IgG2a with intact effector function in combination with an anti-mouse PD-1 antibody was less efficacious than anti-mouse PD-1 alone, suggesting that the effector function of LAG-3 antibody might interfere with anti-mouse PD-1 mediated efficacy. The anti-tumor efficacy of anti-mouse LAG-3 antibodies without effector functions was also observed by other groups $(119,121,122)$.

As of now, there are six LAG-3 antibodies being evaluated in clinical trials. All these LAG-3 antibodies have Fc with either reduced or "null" effector functions. Preliminary data showed that combining anti-LAG-3 therapy (BMS986016) with nivolumab in melanoma patients refractory to $\mathrm{PD}-1 / \mathrm{PD}-\mathrm{L} 1$ treatment could help patients overcome resistance and restore $\mathrm{T}$-cell function with an ORR up to $18 \%$, especially in patients with high LAG-3 expression $(\geq 1 \%)(123)$.

\section{TIGIT}

TIGIT (T cell immunoglobulin and ITIM domain, also known as WUCAM or Vstm3) is a member of the CD28 family of proteins that play an important role in inhibiting $\mathrm{T}$ - and NK cell-mediated functional activities in anti-tumor immunity (124126). TIGIT is mainly expressed on T and NK cells. T cells in the tumor microenvironment (3) often co-express TIGIT with other "checkpoint" inhibitory immune receptors, such as PD-1, LAG-3, and TIM-3 $(93,127)$.

Two TIGIT ligands, CD155 (PVR) and CD112 (PVRL2, nectin-2), have been identified; they are primarily expressed on APCs (such as dendritic cells and macrophages) and tumor cells $(125,126,128,129)$. The binding affinity of TIGIT to CD155 (Kd: 1nM) is much higher than to CD112. Whether the TIGIT: CD112 interaction is functionally relevant in mediating inhibitory signals is yet to be determined. High-affinity binding of TIGIT to CD155 could compete with another co-stimulatory receptor, CD226 (DNAM-1), which binds to the same ligands with lower affinity $(K d: \sim 100 \mathrm{nM})$ and delivers a positive signal (130), therefore reducing T- or NK-activation. In addition, the interaction between TIGIT and PVR on dendritic cells (DCs) could deliver a "reverse signaling" in DCs, leading to reduced DC activity and T-cell activation (126). TIGIT expression on Tregs has been associated with a highly immune-suppressive phenotype in tumor tissue and TIGIT signaling in Tregs may favor Treg stability $(131,132)$.

Blockade of the TIGIT receptor alone or in combination with PD-1/PD-L1 blockade could rescue functionally "exhausted" $\mathrm{T}$ cells both in vitro and in vivo $(133,134)$. In the CT26 cancer model, Fc with effector functions is critical for TIGIT antibodymediated anti-tumor activity $(11,135)$. The TIGIT antibody with wild-type (WT) human IgG1 Fc (EOS884448) has been shown to be capable of preferentially depleting Treg cells in vitro (11). The authors demonstrated that the surrogate mouse TIGIT antibody of the mIgG2a isotype has potent anti-tumor activity either as monotherapy or in combination with a PD1 antibody. In contrast, the mouse anti-TIGIT antibody with Fc devoid of effector functions did not show any of the antitumor efficacies, indicating that Fc-mediated effector functions are required for TIGIT antibody-mediated anti-tumor effects. In addition, the observed efficacy was associated with increased activity of effector $\mathrm{T}$ cells $\left(\mathrm{CD} 8^{+}\right.$and $\left.\mathrm{CD} 4^{+}\right)$and also with Treg depletion within the TME. Argast et al. also observed that effector functions were critical for TIGIT antibody-induced in vivo efficacy (135).

To date, there are six TIGIT antibodies (see Table 3 ) in clinical trials, with different IgG isotypes or mutant forms. The most advanced, MTIG7192 (NCT03563716), is in a phase 2 trial in combination with the anti-PD-L1 antibody atezolizumab for treatment of advanced NSCLC. How the effector functions affect clinical activities remains to be seen. 
TABLE 3 | Anti-TIGIT in clinical trials.

\begin{tabular}{llll}
\hline Company & mAb & $\begin{array}{l}\text { Clinical } \\
\text { stages }\end{array}$ & $\begin{array}{l}\text { IgG Isotype and Fc } \\
\text { effector functions }\end{array}$ \\
\hline $\begin{array}{l}\text { Genentech } \\
\text { Merck Sharp \& Dohme }\end{array}$ & MK-7684 & Phase 2 & IgG1 \\
Bristol-Myers Squibb & BMS-986207 & Phase 1/2 & IgG1 \\
Oncomed & OMP- & Phase 1 & IgG1 \\
Arcus & 313M32 & & \\
Potenza & AB-154 & Phase 1 & lgG4 S S228 P \\
\hline
\end{tabular}

\section{CD73}

CD73 (also known as 5'-ecto-nucleotidase, or NT5E) is a glycosylphosphatidylinositol (136) anchored cell surface protein, which has both enzymatic and non-enzymatic functions (137). As a nucleotidase, it catalyzes the extracellular dephosphorylation of adenosine monophosphate (AMP) to adenosine. Adenosine is believed to be an immunosuppressive molecule inhibiting $\mathrm{CD}^{+} \mathrm{T}$ cells, NK cells, and dendritic cells, while promoting the proliferation of immunosuppressive cells $(138,139)$. In some cases, CD73 can be shed from the cell surface with retained enzymatic activity (140). Expression of CD73 varies on normal tissues but remains at constitutively high levels on many types of cancer cells. High CD73 expression has been shown to be correlated with unfavorable clinical outcomes (141147), which is consistent with the immunosuppressive role of adenosine.

Three CD73 blocking antibodies have been entered into clinical trials (i.e., BMS-986179, CPI-006, and MEDI9447). Compared with small-molecule inhibitors, anti-CD73 mAbs offer the possibility of directly targeting both enzymatic and nonenzymatic CD73 pathways (148). In vitro data showed that MEDI9447 (human IgG1 variant) could inhibit the enzymatic activity of both soluble- and membrane-bound CD73 through prevention of the conformational transition of CD73 to an active state, and could induce internalization of membrane-bound CD73, and restore $\mathrm{T}$-cell proliferation from the inhibition by AMP $(149,150)$. In a mouse model, MEDI9447 monotherapy showed significant anti-tumor efficacy, which was further increased when combined with a PD-1 antibody (150). In the Fc region of MEDI9447, triple mutations $\left(\mathrm{L}_{234} \mathrm{~F} / \mathrm{L}_{235} \mathrm{E} / \mathrm{P}_{331} \mathrm{~S}\right)$ were introduced to eliminate its binding to $\mathrm{Fc} \gamma \mathrm{Rs}$ (Including Fc $\gamma$ RI, Fc $\gamma$ RIIa, and Fc $\gamma$ RIIIa) and C1q $(150,151)$. Similarly, CPI-006 from Corvus is also an IgG1 isotype with a "silent" Fc. It could fully block the production of adenosine by inhibiting the enzymatic activity of CD73 (IC50, 17nM) without internalization, while also activate $\mathrm{B}$ cells independent of adenosine reduction (152).

Another anti-CD73 antibody, BMS-986179, is an IgG2/IgG1 hybrid with a "null" effector function. BMS-986179 could not only inhibit CD73 enzymatic function but also induce rapid, near-complete internalization (153). The disulfide bond isomerization of IgG2 is thought to be the major mechanism for BMS-986179-induced CD73 efficient clustering and internalization. Results from mouse models indicated that the combination of PD-1 blockade and a surrogate anti-mouseCD73 antibody treatment resulted in more enhanced anti-tumor efficacy than either treatment alone (153). In a phase $1 / 2 \mathrm{a}$ study (NCT02754141), 59 patients with advanced solid tumors were treated either alone with BMS-986179 or in combination with nivolumab. Preliminary results showed that both the monotherapy of BMS-986179 and the combination were welltolerated and clinical activities were observed with 7 partial responses and 10 stable diseases (154).

\section{VISTA}

VISTA (V-domain Ig-containing Suppressor of $\mathrm{T}$ cell Activation,also known as B7-H5, B7H5, C10orf54, DD1alpha, GI24, PD-1H, PP2135, SISP1) is a type I transmembrane protein with a single extracellular IgV domain, functioning as a negative regulator of T-cell immunity. It is predominantly expressed on hematopoietic cells, at the highest level on myeloid cells and at lower levels on T cells (155). In vitro studies indicated that not only could VISTA-Ig inhibit T-cell activation and proliferation, but it could also induce Treg differentiation (155). The receptor for VISTA remains unknown. Results from murine models suggested that VISTA and PD-1 suppressed T-cell function in a synergistic manner, providing the possibility of combined therapy targeting both VISTA and PD-1 to enhance anti-tumor immunity (156).

To date, JNJ-61610588, a fully human IgG1 antibody (with wild-type Fc) is the only anti-VISTA monoclonal antibody in a clinical trial (NCT02671955). A preliminary study showed that JNJ-61610588 could induce monocytes and T-cell activation, as well as T-cell proliferation in vitro (12). Interestingly, active $\mathrm{Fc}$ and $\mathrm{Fc}$ receptor crosslinking is required for the efficacy, since neither the silent Fc version of VSTB140, with an IgG2 sigma constant region, nor the Fc blocking of JNJ-61610588 exhibited activity. Consistent with in vitro findings, the antitumor activity of JNJ-61610588 in mouse tumor models was observed. The exact mechanisms and clinical evidence remain to be seen.

\section{B7-H3}

B7-H3 (Human B7 homolog 3, also known as CD276) is a member of the B7 family of immune proteins. The majority of studies suggest that B7-H3 is an immune checkpoint molecule (157-159), although it was initially characterized as a costimulatory molecule for T-cell activation and IFN $\gamma$ production (160). The B7-H3 receptor expressed on T cells remains to be identified (161). B7-H3 has limited expression on normal tissues but is preferentially expressed on a wide spectrum of cancer cells and tumor vasculature, which is associated with poor outcomes in multiple cancers (162-168).

MGA271 (or enoblituzumab), is an Fc-enhanced humanized IgG1 anti-B7-H3 antibody developed by MacroGenics. Mutations were introduced in the IgG1 Fc domain to increase its affinity to Fc $\gamma$ RIIIa but decrease the affinity to Fc $\gamma$ RIIb (169). Enhanced ADCC against a wide arrange of B7-H3 positive tumor cell lines (including prostate, lung, breast, colon, bladder, renal cancers and melanoma) was observed across all the 
donors with different FcyRIIIa polymorphisms (low-affinity $158 \mathrm{~F}$ homozygous, high-affinity $158 \mathrm{~V}$ homozygous, and 158F/V heterozygous). Consistent with in vitro data, greater anti-tumor efficacy was observed in the group with MGA271 than the one with wildtype IgG1 Fc in human Fc $\gamma$ RIIIa-158F-transgenic mice (170). Initial evidence of anti-tumor activity was observed in a clinical trial with MGA271, with no dose-limiting toxicities or severe immune-related side effects (171).

\section{CONCLUDING REMARKS}

In this review, we have summarized recent advances in the study of Fc $\gamma$ R-binding on checkpoint antibody therapy. For targets such as CTLA-4, multiple studies indicated the critical role of competent IgG1-Fc for anti-CTLA-4 antibody-mediated intratumoral depletion of Tregs via ADCC $(10,15)$. This MOA may largely be attributed to the preferential surface expression of CTLA-4 on Tregs and the presence of significant numbers of $\mathrm{CD}_{16}{ }^{+}$macrophages inside tumors (15). In mouse models, anti-CTLA-4 mAbs do not block CTLA-4-B7 interaction, yet they remain active in anti-tumor efficacy, suggesting that intratumoral depletion of Tregs by anti-CTLA- 4 antibodies might be the primary MOA (172). A similar phenomenon was observed for TIGIT or VISTA in mouse models, in which their antibodyelicited anti-tumor efficacy is mainly dependent on Fc-mediated effector functions (11).

So far, five approved anti-PD-1 mAbs (nivolumab, pembrolizumab, and cemiplimab) are of human IgG4 isotype. The choice was made primarily based on the fact that the affinity of IgG4 to Fc $\gamma$ RIIIa is very low, inducing little ADCC (13). However, IgG4 binds to Fc $\gamma$ RI with high affinity, which can negatively impact the efficacy of PD-1 therapy $(9,37)$. Moreover, IgG4 can also bind to Fc $\gamma$ RIIb, leading to reduced anti-tumor efficacy, likely through the induction of a more immunosuppressive environment $(9,78)$. Therefore, an IgG variant of the anti-PD-1 antibody with null Fc $\gamma \mathrm{R}$-binding is expected to be the optimal candidate for therapeutic blocking of PD-1 without the unwanted engagement of $\mathrm{Fc} \gamma \mathrm{R}$ pathways. A similar rationale applies to co-inhibitory receptors TIM-3 and LAG-3, in which blocking antibody-mediated anti-tumor

\section{REFERENCES}

1. Pardoll DM. The blockade of immune checkpoints in cancer immunotherapy. Nat Rev Cancer (2012) 12:252-64. doi: 10.1038/nrc3239

2. Topalian SL, Drake CG, Pardoll DM. Immune checkpoint blockade: a common denominator approach to cancer therapy. Cancer Cell (2015) 27:450-61. doi: 10.1016/j.ccell.2015.03.001

3. Dietze KK, Zelinskyy G, Liu J, Kretzmer F, Schimmer S, Dittmer U. Combining regulatory $\mathrm{T}$ cell depletion and inhibitory receptor blockade improves reactivation of exhausted virus-specific CD8 $\mathrm{T}$ cells and efficiently reduces chronic retroviral loads. PLoS Pathog. (2013) 9:e1003798. doi: 10.1371/journal.ppat.1003798

4. Wei SC, Duffy CR, Allison JP. Fundamental mechanisms of immune checkpoint blockade therapy. Cancer Discov. (2018) 8:1069-86. doi: 10.1158/2159-8290.CD-18-0367 efficacy might be compromised when the Fc maintains intact effector functions.

Three PD-L1-targeting mAbs have been approved: atezolizumab, durvalumab (IgG1 variant with null or reduced $\mathrm{Fc}-\mathrm{Fc} \gamma \mathrm{R}$ binding), and avelumab (wild-type IgG1, ADCCenabling) (173). Comparison of clinical activities of these mAbs may provide important insight into the contribution of $\mathrm{Fc} \gamma \mathrm{Rs}$ for the anti-PD-L1 treatment of human cancers.

It should be noted that most of the findings in this review about the role of IgG antibody and Fc $\gamma \mathrm{R}$ binding on immuneoncology therapy were obtained from mouse models (some even in human Fc $\gamma$ R-transgenic mice). There are several factors that need to be taken into consideration, including, how well the mouse $\mathrm{F} c \gamma \mathrm{R}$ expression pattern (including transgenic human $\mathrm{F} c \gamma \mathrm{Rs})$ mimics the human counterpart, especially in cancer patients, and how different the abundance and distribution of $\mathrm{F} c \gamma \mathrm{R}^{+}$effector cells (e.g., NK cells and macrophages) are in mice vs. in humans in the TME. Studies on the impact of human Fc $\gamma R$ polymorphisms (Fc $\gamma$ RIIIa- $\mathrm{V}_{158}$ vs. $\mathrm{F}_{158} ; \mathrm{Fc} \gamma$ RIIa- $\mathrm{H}_{131}$ vs. $\mathrm{R}_{131}$ ) on clinical activity may also shed light on the MOA of immune checkpoint-targeted antibodies (15). In addition, ex vivo assays using human tumor samples and targeted antibodies in various settings may provide useful insight into this matter.

In summary, the triggering of effector functions on $\operatorname{IgG}$ and $\mathrm{F} c \gamma \mathrm{R}$ interactions is a complex process; the overall outcome may be dependent on the target expression level, distribution, and abundance of $\mathrm{T}$ cells, and the $\mathrm{Fc} \gamma \mathrm{R}^{+}$effector cells (NK cells and macrophages) inside tumors. Further investigation through clinical pathology and pharmacology studies is needed to assess the translational applicability of these findings in mouse models to human cancer treatment.

\section{AUTHOR CONTRIBUTIONS}

All authors listed have made a substantial, direct and intellectual contribution to the work, and approved it for publication.

\section{FUNDING}

This review is supported by BeiGene internal funds.

5. Beers SA, Glennie MJ, White AL. Influence of immunoglobulin isotype on therapeutic antibody function. Blood (2016) 127:1097-101. doi: 10.1182/blood-2015-09-625343

6. Brezski RJ, Georgiou G. Immunoglobulin isotype knowledge and application to Fc engineering. Curr Opin Immunol. (2016) 40:62-9. doi: 10.1016/j.coi.2016.03.002

7. Chan AC, Carter PJ. Therapeutic antibodies for autoimmunity and inflammation. Nat Rev Immunol. (2010) 10:301-16. doi: 10.1038/nri2761

8. Marin-Acevedo JA, Dholaria B, Soyano AE, Knutson KL, Chumsri S, Lou Y. Next generation of immune checkpoint therapy in cancer: new developments and challenges. J Hematol Oncol. (2018) 11:39. doi: 10.1186/s13045-018-0582-8

9. Dahan R, Sega E, Engelhardt J, Selby M, Korman AJ, Ravetch JV. FcgammaRs modulate the anti-tumor activity of antibodies targeting the PD-1/PD-L1 axis. Cancer Cell (2015) 28:543. doi: 10.1016/j.ccell.2015.09.011 
10. Simpson TR, Li F, Montalvo-Ortiz W, Sepulveda MA, Bergerhoff K, Arce $\mathrm{F}$, et al. Fc-dependent depletion of tumor-infiltrating regulatory $\mathrm{T}$ cells codefines the efficacy of anti-CTLA-4 therapy against melanoma. J Exp Med. (2013) 210:1695-710. doi: 10.1084/jem.20130579

11. Leroy X, Hoofd C, Cuende J, Denies S, Rabolli V, Preillon J, et al. Abstract LB-114: a-TIGIT antagonist antibody EOS884448 shows dual mechanism of action by restoration of $\mathrm{T}$ cell effector functions and preferential depletion of Treg. Cancer Res. (2018) 78(13 Supplement):LB-114-LB-14. doi: 10.1158/1538-7445.Am2018-lb-114

12. Snyder LA. JNJ-61610588: A human anti-VISTA antibody induces antitumor responses via a unique mechanism of action. In: AACR Annual Meeting 2016. New Orleans, LA (2016).

13. Bruhns P, Iannascoli B, England P, Mancardi DA, Fernandez N, Jorieux $S$, et al. Specificity and affinity of human Fcgamma receptors and their polymorphic variants for human IgG subclasses. Blood (2009) 113:3716-25. doi: 10.1182/blood-2008-09-179754

14. Vidarsson G, Dekkers G, Rispens T. IgG subclasses and allotypes: from structure to effector functions. Front Immunol. (2014) 5:520. doi: 10.3389/fimmu.2014.00520

15. Arce Vargas F, Furness AJS, Litchfield K, Joshi K, Rosenthal R, Ghorani E, et al. Fc Effector function contributes to the activity of human anti-CTLA-4 antibodies. Cancer Cell (2018) 33:649-63.e4. doi: 10.1016/j.ccell.2018.02.010

16. Oberst MD, Auge C, Morris C, Kentner S, Mulgrew K, McGlinchey K, et al. Potent Immune Modulation by MEDI6383, an Engineered Human OX40 Ligand IgG4P Fc Fusion Protein. Mol Cancer Ther. (2018) 17:1024-38. doi: 10.1158/1535-7163.MCT-17-0200

17. Kono H, Kyogoku C, Suzuki T, Tsuchiya N, Honda H, Yamamoto K, et al. FcgammaRIIB Ile232Thr transmembrane polymorphism associated with human systemic lupus erythematosus decreases affinity to lipid rafts and attenuates inhibitory effects on B cell receptor signaling. Hum Mol Genet. (2005) 14:2881-92. doi: 10.1093/hmg/ddi320

18. Clatworthy MR, Willcocks L, Urban B, Langhorne J, Williams TN, Peshu $\mathrm{N}$, et al. Systemic lupus erythematosus-associated defects in the inhibitory receptor FcgammaRIIb reduce susceptibility to malaria. Proc Natl Acad Sci USA. (2007) 104:7169-74. doi: 10.1073/pnas.0608889104

19. Lu J, Chu J, Zou Z, Hamacher NB, Rixon MW, Sun PD. Structure of FcgammaRI in complex with Fc reveals the importance of glycan recognition for high-affinity IgG binding. Proc Natl Acad Sci USA. (2015) 112:833-8. doi: $10.1073 /$ pnas.1418812112

20. Shields RL, Namenuk AK, Hong K, Meng YG, Rae J, Briggs J, et al. High resolution mapping of the binding site on human IgG1 for FC gamma RI, Fc gamma RII, Fc gamma RIII, and FcRn and design of IgG1 variants with improved binding to the Fc gamma R. J Biol Chem. (2001) 276:6591-604. doi: 10.1074/jbc.M009483200

21. Wines BD, Powell MS, Parren PW, Barnes N, Hogarth PM. The IgG Fc contains distinct $\mathrm{Fc}_{\mathrm{c}}$ receptor $(\mathrm{FcR})$ binding sites: the leukocyte receptors $\mathrm{Fc}$ gamma RI and Fc gamma RIIa bind to a region in the Fc distinct from that recognized by neonatal FcR and protein A. J Immunol. (2000) 164:5313-8. doi: 10.4049/jimmunol.164.10.5313

22. Aalberse RC, Schuurman J. IgG4 breaking the rules. Immunology (2002) 105:9-19. doi: 10.1046/j.0019-2805.2001.01341.x

23. Labrijn AF, Buijsse AO, van den Bremer ET, Verwilligen AY, Bleeker WK, Thorpe SJ, et al. Therapeutic IgG4 antibodies engage in Fab-arm exchange with endogenous human IgG4 in vivo. Nat Biotechnol. (2009) 27:767-71. doi: 10.1038/nbt.1553

24. Yang X, Wang F, Zhang Y, Wang L, Antonenko S, Zhang S, et al. Comprehensive analysis of the therapeutic igg 4 antibody pembrolizumab: hinge modification blocks half molecule exchange in vitro and in vivo. J Pharm Sci. (2015) 104:4002-14. doi: 10.1002/jps.24620

25. Dillon TM, Ricci MS, Vezina C, Flynn GC, Liu YD, Rehder DS, et al. Structural and functional characterization of disulfide isoforms of the human IgG2 subclass. J Biol Chem. (2008) 283:16206-15. doi: 10.1074/jbc.M709988200

26. Wypych J, Li M, Guo A, Zhang Z, Martinez T, Allen MJ, et al. Human IgG2 antibodies display disulfide-mediated structural isoforms. J Biol Chem. (2008) 283:16194-205. doi: 10.1074/jbc.M709987200
27. Liu H, May K. Disulfide bond structures of IgG molecules: structural variations, chemical modifications and possible impacts to stability and biological function. MAbs (2012) 4:17-23. doi: 10.4161/mabs.4.1.18347

28. Liu YD, Chen X, Enk JZ, Plant M, Dillon TM, Flynn GC. Human IgG2 antibody disulfide rearrangement in vivo. J Biol Chem. (2008) 283:29266-72. doi: 10.1074/jbc.M804787200

29. White AL, Chan HT, French RR, Willoughby J, Mockridge CI, Roghanian A, et al. Conformation of the human immunoglobulin G2 hinge imparts superagonistic properties to immunostimulatory anticancer antibodies. Cancer Cell (2015) 27:138-48. doi: 10.1016/j.ccell.2014.11.001

30. Selby MJ, Engelhardt JJ, Quigley M, Henning KA, Chen T, Srinivasan M, et al. Anti-CTLA-4 antibodies of IgG2a isotype enhance antitumor activity through reduction of intratumoral regulatory T cells. Cancer Immunol Res. (2013) 1:32-42. doi: 10.1158/2326-6066.CIR-13-0013

31. Baudino L, Shinohara Y, Nimmerjahn F, Furukawa J, Nakata M, MartinezSoria E, et al. Crucial role of aspartic acid at position 265 in the $\mathrm{CH} 2$ domain for murine IgG2a and IgG2b Fc-associated effector functions. J Immunol. (2008) 181:6664-9. doi: 10.4049/jimmunol.181.9.6664

32. Clynes RA, Towers TL, Presta LG, Ravetch JV. Inhibitory Fc receptors modulate in vivo cytotoxicity against tumor targets. Nat Med. (2000) 6:443-6. doi: $10.1038 / 74704$

33. Smith KG, Clatworthy MR. FcgammaRIIB in autoimmunity and infection: evolutionary and therapeutic implications. Nat Rev Immunol. (2010) 10:32843. doi: $10.1038 /$ nri2762

34. Swisher JF, Feldman GM. The many faces of FcgammaRI: implications for therapeutic antibody function. Immunol Rev. (2015) 268:160-74. doi: 10.1111 /imr.12334

35. Nimmerjahn F, Ravetch JV. Fcgamma receptors as regulators of immune responses. Nat Rev Immunol. (2008) 8:34-47. doi: 10.1038/nri2206

36. Brandsma AM, Schwartz SL, Wester MJ, Valley CC, Blezer GLA, Vidarsson $\mathrm{G}$, et al. Mechanisms of inside-out signaling of the high-affinity IgG receptor FcgammaRI. Sci Signal. (2018) 11:eaaq0891. doi: 10.1126/scisignal.aaq0891

37. Zhang T, Song X, Xu L, Ma J, Zhang Y, Gong W, et al. The binding of an anti-PD-1 antibody to FcgammaRIota has a profound impact on its biological functions. Cancer Immunol Immunother. (2018) 67:1079-90. doi: $10.1007 / \mathrm{s} 00262-018-2160-\mathrm{x}$

38. Ioan-Facsinay A, de Kimpe SJ, Hellwig SM, van Lent PL, Hofhuis FM, van Ojik HH, et al. Fc $\gamma$ RI (CD64) contributes substantially to severity of arthritis, hypersensitivity responses, and protection from bacterial infection. Immunity (2002) 16:391-402. doi: 10.1016/S1074-7613(02)00294-7

39. Mancardi DA, Albanesi M, Jonsson F, Iannascoli B, Van Rooijen N, Kang X, et al. The high-affinity human IgG receptor FcgammaRI (CD64) promotes IgG-mediated inflammation, anaphylaxis, and antitumor immunotherapy. Blood (2013) 121:1563-73. doi: 10.1182/blood-2012-07-442541

40. Clark MR, Stuart SG, Kimberly RP, Ory PA, Goldstein IM. A single amino acid distinguishes the high-responder from the low-responder form of Fc receptor II on human monocytes. Eur J Immunol. (1991) 21:1911-6. doi: 10.1002/eji.1830210820

41. Koene HR, Kleijer M, Algra J, Roos D, von dem Borne AE, de Haas M. Fc gammaRIIIa-158V/F polymorphism influences the binding of IgG by natural killer cell Fc gammaRIIIa, independently of the Fc gammaRIIIa-48L/R/H phenotype. Blood (1997) 90:1109-14.

42. Wu J, Edberg JC, Redecha PB, Bansal V, Guyre PM, Coleman K, et al. A novel polymorphism of FcgammaRIIIa (CD16) alters receptor function and predisposes to autoimmune disease. J Clin Invest. (1997) 100:1059-70. doi: 10.1172/JCI119616

43. Ganesan LP, Kim J, Wu Y, Mohanty S, Phillips GS, Birmingham DJ, et al. FcgammaRIIb on liver sinusoidal endothelium clears small immune complexes. J Immunol. (2012) 189:4981-8. doi: 10.4049/jimmunol. 1202017

44. Li F, Ravetch JV. Antitumor activities of agonistic anti-TNFR antibodies require differential FcgammaRIIB coengagement in vivo. Proc Natl Acad Sci USA. (2013) 110:19501-6. doi: 10.1073/pnas.1319502110

45. Li F, Ravetch JV. Apoptotic and antitumor activity of death receptor antibodies require inhibitory Fcgamma receptor engagement. Proc Natl Acad Sci USA. (2012) 109:10966-71. doi: 10.1073/pnas.1208698109 
46. Nimmerjahn F, Bruhns P, Horiuchi K, Ravetch JV. FcgammaRIV: a novel FcR with distinct IgG subclass specificity. Immunity (2005) 23:41-51. doi: 10.1016/j.immuni.2005.05.010

47. Nimmerjahn F, Lux A, Albert H, Woigk M, Lehmann C, Dudziak D, et al. FcgammaRIV deletion reveals its central role for IgG2a and IgG2b activity in vivo. Proc Natl Acad Sci USA. (2010) 107:19396-401. doi: $10.1073 /$ pnas. 1014515107

48. Bolt S, Routledge E, Lloyd I, Chatenoud L, Pope H, Gorman SD, et al. The generation of a humanized, non-mitogenic CD3 monoclonal antibody which retains in vitro immunosuppressive properties. Eur J Immunol. (1993) 23:403-11. doi: 10.1002/eji.1830230216

49. Xu D, Alegre ML, Varga SS, Rothermel AL, Collins AM, Pulito VL, et al. In vitro characterization of five humanized OKT3 effector function variant antibodies. Cell Immunol. (2000) 200:16-26. doi: 10.1006/cimm.2000.1617

50. An Z, Forrest G, Moore R, Cukan M, Haytko P, Huang L, et al. IgG2m4, an engineered antibody isotype with reduced Fc function. MAbs (2009) 1:572-9. doi: 10.4161/mabs.1.6.10185

51. Teft WA, Kirchhof MG, Madrenas J. A molecular perspective of CTLA-4 function. Annu Rev Immunol. (2006) 24:65-97. doi: 10.1146/annurev.immunol.24.021605.090535

52. Pentcheva-Hoang T, Egen JG, Wojnoonski K, Allison JP. B7-1 and B72 selectively recruit CTLA- 4 and CD28 to the immunological synapse. Immunity (2004) 21:401-13. doi: 10.1016/j.immuni.2004.06.017

53. Jansson A, Barnes E, Klenerman P, Harlen M, Sorensen P, Davis SJ, et al. A theoretical framework for quantitative analysis of the molecular basis of costimulation. J Immunol. (2005) 175:1575-85. doi: 10.4049/jimmunol.175.3.1575

54. Wing K, Onishi Y, Prieto-Martin P, Yamaguchi T, Miyara M, Fehervari Z, et al. CTLA-4 control over Foxp3+ regulatory T cell function. Science (2008) 322:271-5. doi: 10.1126/science.1160062

55. Walker LS, Sansom DM. Confusing signals: recent progress in CTLA-4 biology. Trends Immunol. (2015) 36:63-70. doi: 10.1016/j.it.2014.12.001

56. Bulliard Y, Jolicoeur R, Windman M, Rue SM, Ettenberg S, Knee DA, et al. Activating $\mathrm{Fc}$ gamma receptors contribute to the antitumor activities of immunoregulatory receptor-targeting antibodies. J Exp Med. (2013) 210:1685-93. doi: 10.1084/jem.20130573

57. Motzer RJ, Tannir NM, McDermott DF, Aren Frontera O, Melichar B, Choueiri TK, et al. Nivolumab plus ipilimumab versus sunitinib in advanced renal-cell carcinoma. N Engl J Med. (2018) 378:1277-90. doi: 10.1056/NEJMoa1712126

58. Hellmann MD, Ciuleanu TE, Pluzanski A, Lee JS, Otterson GA, AudigierValette C, et al. Nivolumab plus ipilimumab in lung cancer with a high tumor mutational burden. N Engl J Med. (2018) 378:2093-104. doi: 10.1056/NEJMoa1801946

59. Du X, Liu M, Su J, Zhang P, Tang F, Ye P, et al. Uncoupling therapeutic from immunotherapy-related adverse effects for safer and effective antiCTLA-4 antibodies in CTLA4 humanized mice. Cell Res. (2018) 28:433-47. doi: 10.1038/s41422-018-0012-z

60. Romano E, Kusio-Kobialka M, Foukas PG, Baumgaertner P, Meyer $\mathrm{C}$, Ballabeni $\mathrm{P}$, et al. Ipilimumab-dependent cell-mediated cytotoxicity of regulatory $\mathrm{T}$ cells ex vivo by nonclassical monocytes in melanoma patients. Proc Natl Acad Sci USA. (2015) 112:6140-5. doi: 10.1073/pnas.14 17320112

61. Hanson DC, Canniff PC, Primiano MJ, Donovan CB, Gardner JP, Natoli EJ, et al. Preclinical in vitro characterization of anti-CTLA4 therapeutic antibody CP-675,206. In: AACR Annual Meeting 2004. Orlando, FL (2004). p. 877-77.

62. Sharma A, Subudhi SK, Blando J, Scutti J, Vence L, Wargo J, et al. Anti-CTLA-4 Immunotherapy does not deplete FOXP3(+) regulatory T Cells (Tregs) in human cancers. Clin Cancer Res. (2019) 25:1233-8. doi: 10.1158/1078-0432.CCR-18-0762

63. Liakou CI, Kamat A, Tang DN, Chen H, Sun J, Troncoso P, et al. CTLA-4 blockade increases IFNgamma-producing CD4+ICOShi cells to shift the ratio of effector to regulatory $\mathrm{T}$ cells in cancer patients. Proc Natl Acad Sci USA. (2008) 105:14987-92. doi: 10.1073/pnas.080 6075105

64. Ishida Y, Agata Y, Shibahara K, Honjo T. Induced expression of PD-1, a novel member of the immunoglobulin gene superfamily, upon programmed cell death. EMBO J. (1992) 11:3887-95.
65. Yao S, Chen L. PD-1 as an immune modulatory receptor. Cancer J. (2014) 20:262-4. doi: 10.1097/PPO.0000000000000060

66. Nishimura H, Nose M, Hiai H, Minato N, Honjo T. Development of lupuslike autoimmune diseases by disruption of the PD-1 gene encoding an ITIM motif-carrying immunoreceptor. Immunity (1999) 11:141-51.

67. Agata $\mathrm{Y}$, Kawasaki A, Nishimura H, Ishida Y, Tsubata T, Yagita H, et al. Expression of the PD-1 antigen on the surface of stimulated mouse $\mathrm{T}$ and B lymphocytes. Int Immunol. (1996) 8:765-72.

68. Yao S, Wang S, Zhu Y, Luo L, Zhu G, Flies S, et al. PD-1 on dendritic cells impedes innate immunity against bacterial infection. Blood (2009) 113:5811-8. doi: 10.1182/blood-2009-02-203141

69. Said EA, Dupuy FP, Trautmann L, Zhang Y, Shi Y, El-Far M, et al. Programmed death-1-induced interleukin-10 production by monocytes impairs CD4+ T cell activation during HIV infection. Nat Med. (2010) 16:452-9. doi: 10.1038/nm.2106

70. Dong H, Strome SE, Salomao DR, Tamura H, Hirano F, Flies DB, et al. Tumor-associated B7-H1 promotes T-cell apoptosis: a potential mechanism of immune evasion. Nat Med. (2002) 8:793-800. doi: 10.1038/nm730

71. Ahmadzadeh M, Johnson LA, Heemskerk B, Wunderlich JR, Dudley ME, White DE, et al. Tumor antigen-specific CD8 T cells infiltrating the tumor express high levels of PD-1 and are functionally impaired. Blood (2009) 114:1537-44. doi: 10.1182/blood-2008-12-195792

72. Latchman Y, Wood CR, Chernova T, Chaudhary D, Borde M, Chernova I, et al. PD-L2 is a second ligand for PD-1 and inhibits T cell activation. Nat Immunol. (2001) 2:261-8. doi: 10.1038/85330

73. Topalian SL, Hodi FS, Brahmer JR, Gettinger SN, Smith DC, McDermott DF, et al. Safety, activity, and immune correlates of anti-PD-1 antibody in cancer. N Engl J Med. (2012) 366:2443-54. doi: 10.1056/NEJMoa1200690

74. Arlauckas SP, Garris CS, Kohler RH, Kitaoka M, Cuccarese MF, Yang KS, et al. In vivo imaging reveals a tumor-associated macrophage-mediated resistance pathway in anti-PD-1 therapy. Sci Transl Med. (2017) 9:eaal3604. doi: 10.1126/scitranslmed.aal3604

75. Champiat S, Dercle L, Ammari S, Massard C, Hollebecque A, Postel-Vinay $\mathrm{S}$, et al. Hyperprogressive Disease is a new pattern of progression in cancer patients treated by anti-PD-1/PD-L1. Clin Cancer Res. (2017) 23:1920-28. doi: 10.1158/1078-0432.CCR-16-1741

76. Saada-Bouzid E, Defaucheux C, Karabajakian A, Coloma VP, Servois V, Paoletti $\mathrm{X}$, et al. Hyperprogression during anti-PD-1/PD-L1 therapy in patients with recurrent and/or metastatic head and neck squamous cell carcinoma. Ann Oncol. (2017) 28:1605-11. doi: 10.1093/annonc/mdx178

77. Ferrara R, Mezquita L, Texier M, Lahmar J, Audigier-Valette C, Tessonnier L, et al. Hyperprogressive disease in patients with advanced non-small cell lung cancer treated with PD-1/PD-L1 inhibitors or with single-agent chemotherapy. JAMA Oncol. (2018) 4:1543-52. doi: 10.1001/jamaoncol.2018.3676

78. Lo Russo G, Moro M, Sommariva M, Cancila V, Boeri M, Centonze $\mathrm{G}$, et al. Antibody-Fc/FcR interaction on macrophages as a mechanism for hyperprogressive disease in non-small cell lung cancer subsequent to PD-1/PD-L1 blockade. Clin Cancer Res. (2018) 25:989-99. doi: 10.1158/1078-0432.CCR-18-1390

79. Dong H, Zhu G, Tamada K, Chen L. B7-H1, a third member of the B7 family, co-stimulates T-cell proliferation and interleukin-10 secretion. Nat Med. (1999) 5:1365-9. doi: 10.1038/70932

80. Hori J, Wang M, Miyashita M, Tanemoto K, Takahashi H, Takemori $\mathrm{T}$, et al. B7-H1-induced apoptosis as a mechanism of immune privilege of corneal allografts. J Immunol. (2006) 177:5928-35. doi: 10.4049/jimmunol.177.9.5928

81. Petroff MG, Chen L, Phillips TA, Hunt JS. B7 family molecules: novel immunomodulators at the maternal-fetal interface. Placenta (2002) 23(Suppl. A):S95-101). doi: 10.1053/plac.2002.0813

82. Keir ME, Butte MJ, Freeman GJ, Sharpe AH. PD-1 and its ligands in tolerance and immunity. Annu Rev Immunol. (2008) 26:677-704. doi: 10.1146/annurev.immunol.26.021607.090331

83. Patel SP, Kurzrock R. PD-L1 expression as a predictive biomarker in cancer immunotherapy. Mol Cancer Ther. (2015) 14:847-56. doi: 10.1158/1535-7163.MCT-14-0983

84. Kowanetz M, Zou W, Gettinger SN, Koeppen H, Kockx M, Schmid P, et al. Differential regulation of PD-L1 expression by immune and tumor cells in 
NSCLC and the response to treatment with atezolizumab (anti-PD-L1). Proc Natl Acad Sci USA. (2018) 115:E10119-26. doi: 10.1073/pnas.1802166115

85. Inman BA, Longo TA, Ramalingam S, Harrison MR. Atezolizumab: a PD-L1blocking antibody for bladder cancer. Clin Cancer Res. (2017) 23:1886-90. doi: 10.1158/1078-0432.CCR-16-1417

86. Ibrahim R, Stewart R, Shalabi A. PD-L1 blockade for cancer treatment: MEDI4736. Semin Oncol. (2015) 42:474-83. doi: 10.1053/j.seminoncol.2015.02.007

87. Boyerinas B, Jochems C, Fantini M, Heery CR, Gulley JL, Tsang KY, et al. Antibody-dependent cellular cytotoxicity activity of a novel anti-PD-L1 antibody avelumab (MSB0010718C) on human tumor cells. Cancer Immunol Res. (2015) 3:1148-57. doi: 10.1158/2326-6066.CIR-15-0059

88. Dahan R, Sega E, Engelhardt J, Selby M, Korman AJ, Ravetch JV. FcgammaRs modulate the anti-tumor activity of antibodies targeting the PD-1/PD-L1 axis. Cancer Cell (2015) 28:285-95. doi: 10.1016/j.ccell.2015.08.004

89. Goletz C, Lischke T, Harnack U, Schiele P, Danielczyk A, Ruhmann $\mathrm{J}$, et al. Glyco-Engineered anti-human programmed death-ligand 1 antibody mediates stronger CD8 $\mathrm{T}$ cell activation than its normal glycosylated and non-glycosylated counterparts. Front Immunol. (2018) 9:1614. doi: 10.3389/fimmu.2018.01614

90. Sabatos CA, Chakravarti S, Cha E, Schubart A, Sanchez-Fueyo A, Zheng $\mathrm{XX}$, et al. Interaction of Tim-3 and Tim-3 ligand regulates T helper type 1 responses and induction of peripheral tolerance. Nat Immunol. (2003) 4:1102-10. doi: $10.1038 /$ ni988

91. Anderson AC, Anderson DE. TIM-3 in autoimmunity. Curr Opin Immunol. (2006) 18:665-9. doi: 10.1016/j.coi.2006.09.009

92. Anderson AC, Joller N, Kuchroo VK. Lag-3, Tim-3, and TIGIT: co-inhibitory receptors with specialized functions in immune regulation. Immunity (2016) 44:989-1004. doi: 10.1016/j.immuni.2016.05.001

93. Fourcade J, Sun Z, Benallaoua M, Guillaume P, Luescher IF, Sander C, et al. Upregulation of Tim-3 and PD-1 expression is associated with tumor antigen-specific CD8+ T cell dysfunction in melanoma patients. J Exp Med. (2010) 207:2175-86. doi: 10.1084/jem.20100637

94. Sakuishi K, Apetoh L, Sullivan JM, Blazar BR, Kuchroo VK, Anderson AC. Targeting Tim-3 and PD-1 pathways to reverse T cell exhaustion and restore anti-tumor immunity. J Exp Med. (2010) 207:2187-94. doi: 10.1084/jem.20100643

95. Gao X, Zhu Y, Li G, Huang H, Zhang G, Wang F, et al. TIM3 expression characterizes regulatory $\mathrm{T}$ cells in tumor tissues and is associated with lung cancer progression. PLoS ONE (2012) 7:e30676. doi: 10.1371/journal.pone.0030676

96. Yan J, Zhang Y, Zhang JP, Liang J, Li L, Zheng L. Tim-3 expression defines regulatory T cells in human tumors. PLoS ONE (2013) 8:e58006. doi: 10.1371/journal.pone.0058006

97. Das M, Zhu C, Kuchroo VK. Tim-3 and its role in regulating anti-tumor immunity. Immunol Rev. (2017) 276:97-111. doi: 10.1111/imr.12520

98. Zhuang X, Zhang X, Xia X, Zhang C, Liang X, Gao L, et al. Ectopic expression of TIM-3 in lung cancers: a potential independent prognostic factor for patients with NSCLC. Am J Clin Pathol. (2012) 137:978-85. doi: 10.1309/AJCP9Q6OVLVSHTMY

99. Li H, Wu K, Tao K, Chen L, Zheng Q, Lu X, et al. Tim-3/galectin9 signaling pathway mediates T-cell dysfunction and predicts poor prognosis in patients with hepatitis B virus-associated hepatocellular carcinoma. Hepatology (2012) 56:1342-51. doi: 10.1002/hep. 25777

100. Jiang J, Jin MS, Kong F, Cao D, Ma HX, Jia Z, et al. Decreased galectin- 9 and increased Tim- 3 expression are related to poor prognosis in gastric cancer. PLoS ONE (2013) 8:e81799. doi: 10.1371/journal.pone. 0081799

101. Komohara Y, Morita T, Annan DA, Horlad H, Ohnishi K, Yamada $\mathrm{S}$, et al. The coordinated actions of TIM-3 on cancer and myeloid cells in the regulation of tumorigenicity and clinical prognosis in clear cell renal cell carcinomas. Cancer Immunol Res. (2015) 3:999-1007. doi: 10.1158/2326-6066.CIR-14-0156

102. Shayan G, Srivastava R, Li J, Schmitt N, Kane LP, Ferris RL. Adaptive resistance to anti-PD1 therapy by Tim-3 upregulation is mediated by the PI3K-Akt pathway in head and neck cancer. Oncoimmunology (2017) 6:e1261779. doi: 10.1080/2162402X.2016.1261779
103. Koyama S, Akbay EA, Li YY, Herter-Sprie GS, Buczkowski KA, Richards WG, et al. Adaptive resistance to therapeutic PD-1 blockade is associated with upregulation of alternative immune checkpoints. Nat Commun. (2016) 7:10501. doi: $10.1038 /$ ncomms10501

104. Datar I, Mani N, Henick BS, Wurtz A, Kaftan E, Herbst RS, et al. Measurement of PD-1, TIM-3 and LAG-3 protein in non-small cell lung carcinomas (NSCLCs) with acquired resistance to PD1 axis blockers. J Clin Oncol. (2017) 35(15_suppl.):e14611-11. doi: 10.1200/JCO.2017.35.15_suppl.e14611

105. Golden-Mason L, Palmer BE, Kassam N, Townshend-Bulson L, Livingston S, McMahon BJ, et al. Negative immune regulator Tim-3 is overexpressed on $\mathrm{T}$ cells in hepatitis $\mathrm{C}$ virus infection and its blockade rescues dysfunctional CD4+ and CD8+ T cells. J Virol. (2009) 83:9122-30. doi: 10.1128/JVI.00639-09

106. Waight J, Iyer P, Breous-Nystrom E, Riordan C, Findeis M, Underwood D, et al. Abstract 3825: INCAGN02390, a novel antagonist antibody that targets the co-inhibitory receptor TIM-3. Cancer Res. (2018) 78(13 Supplement):3825-25. doi: 10.1158/1538-7445.Am2018-3825

107. Kehry M, Horlick R, Bowers P, Jun T, da Silva Correia J, Graves J, et al. Abstract 271: Targeting PD-1, TIM-3 and LAG-3 in combination for improved immunotherapy combinations. Cancer Res. (2015) 75(15 Supplement):271-71. doi: 10.1158/1538-7445.Am2015-271

108. Davar D, Boasberg P, Eroglu Z, Falchook G, Gainor J, Hamilton E, et al. A phase 1 study of TSR-022 (Anti-TIM-3) in combination with TSR-042 (AntiPD-1). In 2018 Annual Meeting of the Society for Immunotherapy of Cancer (SITC) Conference. Washington, DC (2018).

109. Triebel F, Jitsukawa S, Baixeras E, Roman-Roman S, Genevee C, ViegasPequignot E, et al. LAG-3, a novel lymphocyte activation gene closely related to CD4. J Exp Med. (1990) 171:1393-405. doi: 10.1084/jem.171.5.1393

110. Okazaki T, Okazaki IM, Wang J, Sugiura D, Nakaki F, Yoshida T, et al. PD-1 and LAG-3 inhibitory co-receptors act synergistically to prevent autoimmunity in mice. J Exp Med. (2011) 208:395-407. doi: $10.1084 /$ jem. 20100466

111. Woo SR, Turnis ME, Goldberg MV, Bankoti J, Selby M, Nirschl CJ, et al. Immune inhibitory molecules LAG-3 and PD-1 synergistically regulate Tcell function to promote tumoral immune escape. Cancer Res. (2012) 72:91727. doi: 10.1158/0008-5472.CAN-11-1620

112. Workman CJ, Cauley LS, Kim IJ, Blackman MA, Woodland DL, Vignali DA. Lymphocyte activation gene-3 (CD223) regulates the size of the expanding $\mathrm{T}$ cell population following antigen activation in vivo. J Immunol. (2004) 172:5450-5. doi: 10.4049/jimmunol.172.9.5450

113. Huang CT, Workman CJ, Flies D, Pan X, Marson AL, Zhou G, et al. Role of LAG-3 in regulatory T cells. Immunity (2004) 21:503-13. doi: 10.1016/j.immuni.2004.08.010

114. Huard B, Prigent P, Tournier M, Bruniquel D, Triebel F. CD4/major histocompatibility complex class II interaction analyzed with CD4- and lymphocyte activation gene-3 (LAG-3)-Ig fusion proteins. Eur J Immunol. (1995) 25:2718-21. doi: 10.1002/eji.1830250949

115. Matsuzaki J, Gnjatic S, Mhawech-Fauceglia P, Beck A, Miller A, Tsuji T, et al. Tumor-infiltrating NY-ESO-1-specific CD8 + T cells are negatively regulated by LAG-3 and PD-1 in human ovarian cancer. Proc Natl Acad Sci USA. (2010) 107:7875-80. doi: 10.1073/pnas.1003345107

116. Grosso JF, Kelleher CC, Harris TJ, Maris CH, Hipkiss EL, De Marzo A, et al. LAG-3 regulates CD8+ T cell accumulation and effector function in murine self- and tumor-tolerance systems. J Clin Invest. (2007) 117:3383-92. doi: 10.1172/JCI31184

117. Kouo T, Huang L, Pucsek AB, Cao M, Solt S, Armstrong T, et al. Galectin-3 shapes antitumor immune responses by suppressing CD8+ T cells via LAG3 and inhibiting expansion of plasmacytoid dendritic cells. Cancer Immunol Res. (2015) 3:412-23. doi: 10.1158/2326-6066.CIR-14-0150

118. Wang J, Sanmamed MF, Datar I, Su TT, Ji L, Sun J, et al. Fibrinogenlike Protein 1 is a major immune inhibitory ligand of LAG-3. Cell (2019) 176:334-47.e12. doi: 10.1016/j.cell.2018.11.010

119. Haines BB, Javaid S, Cui L, Hirsch H, Cemerski S, McClanahan T, et al. Abstract 4714: blockade of LAG-3 amplifies immune activation signatures and augments curative antitumor responses to anti-PD-1 therapy in immune competent mouse models of cancer. Cancer Res. (2017) 77(13 Supplement):4714-14. doi: 10.1158/1538-7445.Am2017-4714 
120. Jun HT, Kehry M, Bowers P, King DJ. Antibodies Directed Against Lymphocyte Activation Gene 3 (lag-3). San Diego, CA: US20180127496A (2018).

121. Zettl M, Wurm M, Schaaf O, Tirapu I, Mostböck S, Reschke M, et al. Abstract 4547: characterization of the LAG-3 targeting antibody BI 754111 in monotherapy and in combination with the anti-PD1 antibody BI 754091. Cancer Res. (2018) 78(13 Supplement):4547-47. doi: 10.1158/1538-7445.Am2018-4547

122. Savitsky D, Ward R, Riordan C, Mundt C, Jennings S, Connolly $\mathrm{J}$, et al. Abstract 3819: INCAGN02385 is an antagonist antibody targeting the co-inhibitory receptor LAG-3 for the treatment of human malignancies. Cancer Res. (2018) 78(13 Supplement):3819-19. doi: 10.1158/1538-7445.Am2018-3819

123. Ascierto PA, Bono P, Bhatia S, Melero I, Nyakas MS, Svane I, et al. Efficacy of BMS-986016, a monoclonal antibody that targets lymphocyte activation gene-3 (LAG-3), in combination with nivolumab in pts with melanoma who progressed during prior anti-PD-1/PD-L1 therapy (mel prior IO) in all-comer and biomarker-enriched populations. Ann Oncol. (2017) 28(suppl_5):v605-49. doi: 10.1093/annonc/mdx440

124. Boles KS, Vermi W, Facchetti F, Fuchs A, Wilson TJ, Diacovo TG, et al. A novel molecular interaction for the adhesion of follicular CD4 T cells to follicular DC. Eur J Immunol. (2009) 39:695-703. doi: 10.1002/eji.200839116

125. Stanietsky N, Simic H, Arapovic J, Toporik A, Levy O, Novik A, et al. The interaction of TIGIT with PVR and PVRL2 inhibits human NK cell cytotoxicity. Proc Natl Acad Sci USA. (2009) 106:17858-63. doi: 10.1073/pnas.0903474106

126. Yu X, Harden K, Gonzalez LC, Francesco M, Chiang E, Irving B, et al. The surface protein TIGIT suppresses $\mathrm{T}$ cell activation by promoting the generation of mature immunoregulatory dendritic cells. Nat Immunol. (2009) 10:48-57. doi: 10.1038/ni.1674

127. Gros A, Robbins PF, Yao X, Li YF, Turcotte S, Tran E, et al. PD-1 identifies the patient-specific $\mathrm{CD} 8(+)$ tumor-reactive repertoire infiltrating human tumors. J Clin Invest. (2014) 124:2246-59. doi: 10.1172/JCI73639

128. Casado JG, Pawelec G, Morgado S, Sanchez-Correa B, Delgado E, Gayoso I, et al. Expression of adhesion molecules and ligands for activating and costimulatory receptors involved in cell-mediated cytotoxicity in a large panel of human melanoma cell lines. Cancer Immunol Immunother. (2009) 58:1517-26. doi: 10.1007/s00262-009-0682-y

129. Levin SD, Taft DW, Brandt CS, Bucher C, Howard ED, Chadwick EM, et al. Vstm3 is a member of the CD28 family and an important modulator of T-cell function. Eur J Immunol. (2011) 41:902-15. doi: 10.1002/eji.201041136

130. Bottino C, Castriconi R, Pende D, Rivera P, Nanni M, Carnemolla B, et al. Identification of PVR (CD155) and Nectin-2 (CD112) as cell surface ligands for the human DNAM-1 (CD226) activating molecule. J Exp Med. (2003) 198:557-67. doi: 10.1084/jem.20030788

131. Kurtulus S, Sakuishi K, Ngiow SF, Joller N, Tan DJ, Teng MW, et al. TIGIT predominantly regulates the immune response via regulatory $\mathrm{T}$ cells. J Clin Invest. (2015) 125:4053-62. doi: 10.1172/JCI81187

132. Joller N, Lozano E, Burkett PR, Patel B, Xiao S, Zhu C, et al. Treg cells expressing the coinhibitory molecule TIGIT selectively inhibit proinflammatory Th1 and Th17 cell responses. Immunity (2014) 40:569-81. doi: 10.1016/j.immuni.2014.02.012

133. Johnston RJ, Comps-Agrar L, Hackney J, Yu X, Huseni M, Yang Y, et al. The immunoreceptor TIGIT regulates antitumor and antiviral CD8(+) T cell effector function. Cancer Cell (2014) 26:923-37. doi: 10.1016/j.ccell.2014.10.018

134. Chauvin JM, Pagliano O, Fourcade J, Sun Z, Wang H, Sander C, et al. TIGIT and PD-1 impair tumor antigen-specific CD8(+) T cells in melanoma patients. J Clin Invest. (2015) 125:2046-58. doi: 10.1172/JCI80445

135. Argast GM, Cancilla B, Cattaruzza F, Yeung P, Scolan El, Harris R, et al. Abstract 5627: anti-TIGIT biomarker study: inhibition of TIGIT induces loss of Tregs from tumors and requires effector function for tumor growth inhibition. Cancer Res. (2018) 78(13 Supplement):5627-27. doi: 10.1158/1538-7445.Am2018-5627

136. Barnhart BC, Sega E, Yamniuk A, Hatcher S, Lei M, Ghermazien H, et al. Abstract 1476: a therapeutic antibody that inhibits CD73 activity by dual mechanisms. Cancer Res. (2016) 76(14 Supplement):1476-76. doi: 10.1158/1538-7445.am2016-1476
137. Gao ZW, Wang HP, Lin F, Wang X, Long M, Zhang HZ, et al. CD73 promotes proliferation and migration of human cervical cancer cells independent of its enzyme activity. BMC Cancer (2017) 17:135. doi: 10.1186/s12885-017-3128-5

138. Antonioli L, Yegutkin GG, Pacher P, Blandizzi C, Hasko G. Anti-CD73 in cancer immunotherapy: awakening new opportunities. Trends Cancer (2016) 2:95-109. doi: 10.1016/j.trecan.2016.01.003

139. Gao ZW, Dong K, Zhang HZ. The roles of CD73 in cancer. Biomed Res Int. (2014) 2014:460654. doi: 10.1155/2014/460654

140. Klemens MR, Sherman WR, Holmberg NJ, Ruedi JM, Low MG, Thompson LF. Characterization of soluble vs membrane-bound human placental 5'nucleotidase. Biochem Biophys Res Commun. (1990) 172:1371-7.

141. Inoue $\mathrm{Y}$, Yoshimura $\mathrm{K}$, Kurabe $\mathrm{N}$, Kahyo $\mathrm{T}$, Kawase $\mathrm{A}$, Tanahashi $\mathrm{M}$, et al. Prognostic impact of $\mathrm{CD} 73$ and $\mathrm{A} 2 \mathrm{~A}$ adenosine receptor expression in non-small-cell lung cancer. Oncotarget (2017) 8:8738-51. doi: 10.18632/oncotarget.14434

142. Leclerc BG, Charlebois R, Chouinard G, Allard B, Pommey S, Saad F, et al. CD73 Expression is an independent prognostic factor in prostate cancer. Clin Cancer Res. (2016) 22:158-66. doi: 10.1158/1078-0432.CCR-15-1181

143. Loi S, Pommey S, Haibe-Kains B, Beavis PA, Darcy PK, Smyth MJ, et al. CD73 promotes anthracycline resistance and poor prognosis in triple negative breast cancer. Proc Natl Acad Sci USA. (2013) 110:11091-6. doi: 10.1073/pnas.1222251110

144. Gaudreau PO, Allard B, Turcotte M, Stagg J. CD73-adenosine reduces immune responses and survival in ovarian cancer patients. Oncoimmunology (2016) 5:e1127496. doi: 10.1080/2162402X.2015.1127496

145. Wu XR, He XS, Chen YF, Yuan RX, Zeng Y, Lian L, et al. High expression of CD73 as a poor prognostic biomarker in human colorectal cancer. J Surg Oncol. (2012) 106:130-7. doi: 10.1002/jso.23056

146. Morello S, Capone M, Sorrentino C, Giannarelli D, Madonna G, Mallardo D, et al. Soluble CD73 as biomarker in patients with metastatic melanoma patients treated with nivolumab. J Transl Med. (2017) 15:244. doi: 10.1186/s12967-017-1348-8

147. Ren ZH, Lin CZ, Cao W, Yang R, Lu W, Liu ZQ, et al. CD73 is associated with poor prognosis in HNSCC. Oncotarget (2016) 7:61690-702. doi: 10.18632/oncotarget.11435

148. Vijayan D, Barkauskas DS, Stannard K, Sult E, Buonpane R, Takeda $\mathrm{K}$, et al. Selective activation of anti-CD73 mechanisms in control of primary tumors and metastases. Oncoimmunology (2017) 6:e1312044. doi: 10.1080/2162402X.2017.1312044

149. Geoghegan JC, Diedrich G, Lu X, Rosenthal K, Sachsenmeier KF, Wu $\mathrm{H}$, et al. Inhibition of CD73 AMP hydrolysis by a therapeutic antibody with a dual, non-competitive mechanism of action. MAbs (2016) 8:454-67. doi: $10.1080 / 19420862.2016 .1143182$

150. Hay CM, Sult E, Huang Q, Mulgrew K, Fuhrmann SR, McGlinchey KA, et al. Targeting CD73 in the tumor microenvironment with MEDI9447. Oncoimmunology (2016) 5:e1208875. doi: 10.1080/2162402X.2016.1208875

151. Oganesyan V, Gao C, Shirinian L, Wu H, Dall'Acqua WF. Structural characterization of a human $\mathrm{Fc}$ fragment engineered for lack of effector functions. Acta Crystallogr D Biol Crystallogr. (2008) 64(Pt 6):700-4. doi: $10.1107 /$ S0907444908007877

152. Piccione EC, Hotson A, Mikesell G, Daine-Matsuoka B, Gu C, Dao-Pick T, et al. Preclinical and initial phase I clinical characterization of CPI-006: an anti-CD73 monoclonal antibody with unique immunostimulatory activity. In 2018 Annual Meeting of the Society for Immunotherapy of Cancer (SITC) Conference. Washington, DC (2018).

153. Barnhart BC, Sega E, Yamniuk A, Hatcher S, Lei M, Ghermazien $\mathrm{H}$, et al. Abstract 1476: a therapeutic antibody that inhibits CD73 activity by dual mechanisms. Cancer Res. (2016) 76:1476. doi: 10.1158/1538-7445.AM2016-1476

154. Siu LL, Burris H, Le DT, Hollebecque A, Steeghs N, Delord JP, et al. Abstract CT180: preliminary phase 1 profile of BMS-986179, an anti-CD73 antibody, in combination with nivolumab in patients with advanced solid tumors. Cancer Res. (2018) 78:CT180. doi: 10.1158/1538-7445.AM2018-CT180

155. Lines JL, Pantazi E, Mak J, Sempere LF, Wang L, O’Connell S, et al. VISTA is an immune checkpoint molecule for human T cells. Cancer Res. (2014) 74:1924-32. doi: 10.1158/0008-5472.CAN-13-1504

156. Liu J, Yuan Y, Chen W, Putra J, Suriawinata AA, Schenk AD, et al. Immune-checkpoint proteins VISTA and PD-1 nonredundantly regulate 
murine T-cell responses. Proc Natl Acad Sci USA. (2015) 112:6682-7. doi: $10.1073 /$ pnas. 1420370112

157. Vigdorovich V, Ramagopal UA, Lazar-Molnar E, Sylvestre E, Lee JS, Hofmeyer KA, et al. Structure and T cell inhibition properties of B7 family member, B7-H3. Structure (2013) 21:707-17. doi: 10.1016/j.str.2013.03.003

158. Lee YH, Martin-Orozco N, Zheng P, Li J, Zhang P, Tan H, et al. Inhibition of the B7-H3 immune checkpoint limits tumor growth by enhancing cytotoxic lymphocyte function. Cell Res. (2017) 27:1034-45. doi: 10.1038/cr.2017.90

159. Prasad DV, Nguyen T, Li Z, Yang Y, Duong J, Wang Y, et al. Murine B7-H3 is a negative regulator of T cells. J Immunol. (2004) 173:2500-6. doi: 10.4049/jimmunol.173.4.2500

160. Chapoval AI, Ni J, Lau JS, Wilcox RA, Flies DB, Liu D, et al. B7-H3: a costimulatory molecule for $\mathrm{T}$ cell activation and IFNgamma production. Nat Immunol. (2001) 2:269-74. doi: 10.1038/ 85339

161. Sun M, Richards S, Prasad DV, Mai XM, Rudensky A, Dong C. Characterization of mouse and human B7-H3 genes. J Immunol. (2002) 168:6294-7. doi: 10.4049/jimmunol.168.12.6294

162. Zhang G, Xu Y, Lu X, Huang H, Zhou Y, Lu B, et al. Diagnosis value of serum B7-H3 expression in non-small cell lung cancer. Lung Cancer (2009) 66:245-9. doi: 10.1016/j.lungcan.2009.01.017

163. Zang $\mathrm{X}$, Thompson RH, Al-Ahmadie HA, Serio AM, Reuter VE, Eastham JA, et al. B7-H3 and B7x are highly expressed in human prostate cancer and associated with disease spread and poor outcome. Proc Natl Acad Sci USA. (2007) 104:19458-63. doi: 10.1073/pnas.070 9802104

164. Crispen PL, Sheinin Y, Roth TJ, Lohse CM, Kuntz SM, Frigola X, et al. Tumor cell and tumor vasculature expression of $\mathrm{B} 7-\mathrm{H} 3$ predict survival in clear cell renal cell carcinoma. Clin Cancer Res. (2008) 14:5150-7. doi: 10.1158/1078-0432.CCR-08-0536

165. Roth TJ, Sheinin Y, Lohse CM, Kuntz SM, Frigola X, Inman BA, et al. B7-H3 ligand expression by prostate cancer: a novel marker of prognosis and potential target for therapy. Cancer Res. (2007) 67:7893-900. doi: 10.1158/0008-5472.CAN-07-1068

166. Sun Y, Wang Y, Zhao J, Gu M, Giscombe R, Lefvert AK, et al. B7-H3 and B7H4 expression in non-small-cell lung cancer. Lung Cancer (2006) 53:143-51. doi: 10.1016/j.lungcan.2006.05.012

167. Zang X, Sullivan PS, Soslow RA, Waitz R, Reuter VE, Wilton A, et al. Tumor associated endothelial expression of B7-H3 predicts survival in ovarian carcinomas. Mod Pathol. (2010) 23:1104-12. doi: 10.1038/modpathol.2010.95

168. Seaman S, Zhu Z, Saha S, Zhang XM, Yang MY, Hilton MB, et al. Eradication of tumors through simultaneous ablation of CD276/B7-H3-positive tumor cells and tumor vasculature. Cancer Cell (2017) 31:501-15 e8. doi: 10.1016/j.ccell.2017.03.005

169. Rizvi NA, Loo D, Baughman JE, Yun S, Chen F, Moore PA, et al. A phase 1 study of enoblituzumab in combination with pembrolizumab in patients with advanced B7-H3-expressing cancers. J Clin Oncol. (2016) 34(15_suppl):TPS3104-TPS04. doi: 10.1200/JCO.2016.34.15_suppl.TPS3104

170. Loo D, Alderson RF, Chen FZ, Huang L, Zhang W, Gorlatov S, et al. Development of an Fc-enhanced anti-B7-H3 monoclonal antibody with potent antitumor activity. Clin Cancer Res. (2012) 18:3834-45. doi: 10.1158/1078-0432.CCR-12-0715

171. Powderly J, Cote G, Flaherty K, Szmulewitz RZ, Ribas A, Weber J, et al. Interim results of an ongoing Phase I, dose escalation study of MGA271 (Fc-optimized humanized anti-B7-H3 monoclonal antibody) in patients with refractory B7-H3-expressing neoplasms or neoplasms whose vasculature expresses B7-H3. J ImmunoTher Cancer (2015) 3(Suppl 2): O8. doi: 10.1186/2051-1426-3-S2-O8

172. Du X, Tang F, Liu M, Su J, Zhang Y, Wu W, et al. A reappraisal of CTLA-4 checkpoint blockade in cancer immunotherapy. Cell Res. (2018) 28:416-32. doi: 10.1038/s41422-018-0011-0

173. Gong J, Chehrazi-Raffle A, Reddi S, Salgia R. Development of PD-1 and PDL1 inhibitors as a form of cancer immunotherapy: a comprehensive review of registration trials and future considerations. J Immunother Cancer (2018) 6:8. doi: 10.1186/s40425-018-0316-z

Conflict of Interest Statement: This work was funded by BeiGene. All authors have an ownership interest in BeiGene.

Copyright (c) 2019 Chen, Song, Li and Zhang. This is an open-access article distributed under the terms of the Creative Commons Attribution License (CC BY). The use, distribution or reproduction in other forums is permitted, provided the original author(s) and the copyright owner(s) are credited and that the original publication in this journal is cited, in accordance with accepted academic practice. No use, distribution or reproduction is permitted which does not comply with these terms. 